\title{
Review
}

\section{Current Status of Stem Cell Therapy for Liver Diseases}

\author{
Bruno Solano de Freitas Souza,* Renata Campos Nogueira,* Sheilla Andrade de Oliveira, $\dagger$ \\ Luiz Antonio Rodrigues de Freitas, $* \$$ Luiz Guilherme Costa Lyra, $\$ \S$ Ricardo Ribeiro dos Santos, $* \S$ \\ Andre Castro Lyra, $\$ \S$ and Milena Botelho Pereira Soares*§ \\ *Centro de Pesquisas Gonçalo Moniz, Fundação Oswaldo Cruz, Salvador, Bahia, Brazil \\ $†$ Centro de Pesquisas Aggeu Magalhães, Fundação Oswaldo Cruz, Recife, Pernambuco, Brazil \\ ‡Universidade Federal da Bahia, Salvador, Bahia, Brazil \\ $\S$ Hospital São Rafael, Salvador, Bahia, Brazil
}

\begin{abstract}
Liver failure is one of the main causes of death worldwide and is a growing health problem. Since the discovery of stem cell populations capable of differentiating into specialized cell types, including hepatocytes, the possibility of their utilization in the regeneration of the damaged liver has been a focus of intense investigation. A variety of cell types were tested both in vitro and in vivo, but the definition of a more suitable cell preparation for therapeutic use in each type of liver lesions is yet to be determined. Here we review the protocols described for differentiation of stem cells into hepatocytes, the results of cell therapy in animal models of liver diseases, as well as the available data of the clinical trials in patients with advanced chronic liver disease.
\end{abstract}

Key words: Liver diseases; Liver regeneration; Stem cells; Hepatocytes

\section{INTRODUCTION}

The liver is the target of a number of diseases of acute or chronic courses. Diverse types of hepatic injuries caused by toxic, metabolic, infectious, or traumatic agents lead to series of precisely regulated physiologic events called liver regeneration (32). The hepatocyte is a highly differentiated epithelial cell that maintains the potential of division, being able to enter the cell cycle whenever is necessary. Therefore, liver regeneration is primarily based on the compensatory hyperplasia of the remaining parenchyma that occurs until the original hepatic mass is recovered $(62,87)$.

When the injury process causes impairment in hepatocyte division, however, regeneration can still occur through the activation and differentiation of intrahepatic progenitors called oval cells (86). These cells can differentiate into either hepatocytes or cholangiocytes and can be easily identified in livers of rats submitted to hepatic injury with carbon tetrachloride $\left(\mathrm{CCl}_{4}\right)$ associated with
$\mathrm{N}-2$ acetylaminofluorene (AAF) (141) and also in livers of mice following administration of retrorsine and partial hepatectomy (65). The presence of oval cells in injured livers has also been identified in patients (8). Initially, it was described that oval cells arise from the bile ducts or canals of Hering (128). More recently, the observation that oval cells share some markers with hematopoietic cells, such as CD34, Thy-1, and Sca-1, has led to the hypothesis that oval cells can arise from bone marrow, but the available data are still conflicting $(19,95,132)$. A recent work showed that bone marrow cells can fuse with oval cells (59). Thus, although their existence and bipotential nature are well established, the origin of oval cells remains uncertain. Nonetheless, their important role in hepatic regeneration makes them a putative cell population for therapeutic use in liver diseases.

In addition to oval cells, another cell population known as small hepatocyte-like progenitors was described in rats following hepatectomy and administration of ret- 
rorsine. This cell population is phenotypically distinct from differentiated hepatocytes, cholangiocytes, and oval cells $(39,40)$. There is still controversy whether these cells represent an intermediate state in oval cell differentiation or are derived from hepatocytes resistant to retrorsine treatment $(10,131)$.

According to the described data, hepatic regeneration can occur through three different cell lines: hepatocytes, intrahepatic stem cells, or extrahepatic stem cells (110). Despite the regenerative potential of the liver, chronic and persistent hepatic injuries lead to a sustained woundhealing response and the development of fibrosis. In advanced diseases a distortion of the parenchyma with formation of hepatocellular nodules and fibrous septae characterizes liver cirrhosis. Studies have shown that, even in patients with chronic liver diseases, fibrosis can be reversible when the aggression to the organ is controlled (13).

Liver transplantation is still the only option for patients with end-stage hepatic disease and has limitations like the scarcity of donors, high costs, possibility of rejection, and necessity for immunosuppression.

Hepatocyte transplantation has been investigated as an alternative treatment for several liver diseases. The use of hepatocye infusions was first tested in an experimental model for Crigler-Najjar syndrome (72). Over the years many studies with animal models were used for correction of acute liver failure, inborn errors of metabolism $(43,74,134)$, and to improve liver function of rats with decompensated cirrhosis (58).

The good results obtained in experimental studies with hepatocyte transplantation in models of hepatic injury allowed the proposition of clinical trials in patients with liver diseases. These studies demonstrated the recovery of hepatic encephalopathy in patients with acute hepatic failure $(11,44,56)$, but only in 2 of the 10 cirrhotic patients evaluated (76).

For treatment of liver-based metabolic diseases, hepatocyte transplantation was more successful, as demonstrated in studies with patients with Crigler-Najar syndrome type I, glycogen storage disease, and ornithine transcarbamylase deficiency, among others $(35,48,81)$. However, the clinical trials carried out had few patients included and needed more accurate studies. Moreover, the correction of metabolic defects was transient, suggesting a progressive loss of transplanted cells $(34,111)$. In this setting, stem cells transplantation is of great interest as an alternate and promising therapeutic approach. At this point, however, there is still much to be clarified and some challenges persist. Whether stem cells can help repair injured livers, by which mechanisms, and what would be the ideal cell source are only some of the questions that need to be answered. Also, the protocols involved with stem cell extraction and transplantation are not innocuous, and the procedure-associated risks are increased in patients with chronic liver diseases. Furthermore, bone marrow hypoplasia-frequently found in patients with advanced liver diseases - may limit the number of isolated stem cells. In terms of expanding the cells in vitro, longer time spent and higher costs are still limiting. There is also concern on the possibility of chromosome alterations, which could be induced by longterm cell culture, and risk of malignancies after transplantation (18). Therefore, assessing the real benefits that stem cell therapy may provide to patients with chronic liver diseases will be necessary in order to establish a cost-effectiveness analysis. In the following sections we reviewed available data on in vitro, preclinical, and clinical studies on stem cell therapy and liver diseases.

\section{STEM CELLS: CONCEPTS AND DEFINITIONS}

There are two types of stem cells that can be employed in the regeneration of a damaged liver: embryonic stem cells (ESCs) and adult stem cells. ESCs are derived from the inner cell mass of blastocyst stage embryos $(70,82)$ and adult stem cells, like mesenchymal stem cells (MSCs), that can be isolated from postnatal tissues, expanded in vitro as adhesion-derived cells, and induced to differentiate into multiple cell types (7).

Stem cells can be classified as totipotent, pluripotent, or multipotent. A multipotent cell can give rise to multiple cell types not restricted to a single germ layer. A pluripotent cell should be able to give rise to all cell types that are found in an adult organism. A totipotent cell is a cell that can produce an entire organism, including extraembryonic membranes and placenta. Nowadays, confusion seems to occur with this classification and there is no consensus on the precise meaning of those terms. Although it is possible to derive an entire mouse from an ESC, some authors (114) classify ESCs as pluripotent because a tetraploid embryo would be required to form the extraembryonic membranes and placenta (83). Other authors, however, classify ESCs as totipotent, MSCs as pluripotent, hepatoblast cells as multipotent, and hepatocyte as specialized cells (21).

The development of protocols to induce stem cells to undergo a hepatic-commitment pathway and to finally give rise to functional mature hepatocytes for transplantation is a matter of great interest. Currently, hepatocyte transplantation is still limited by the available supply of liver donors (25) and their rapid elimination by recipient macrophages (38). Being an allogeneic transplant, the fate of transplanted hepatocytes needs investigation (99). Furthermore, specialized cell types, such as mature hepatocytes, cannot be expanded in vitro and techniques to proliferate hepatocyte progenitor cells basically depend on liver donations (109). This could be easily over- 
come by using stem cell cultures, especially ESCs, which are highly proliferative. However, ESCs cells have a high neoplastic potential (Fig. 1) and therefore attention must be paid for the possibility of teratoma development (75). This obstacle makes MSCs a suitable type of stem cells for hepatocyte differentiation due to their good proliferative potential, high plasticity (7), and considerable less neoplastic potential compared to ESC (21). Although MSCs represent a promising source, the achievement of means to overcome technical issues concerning isolation from a given tissue, expansion, differentiation into hepatocyte-like cells procedure, and, especially, making this process an economically viable alternative still remains a challenge.

\section{MOLECULAR MECHANISMS INVOLVED IN THE EARLY DEVELOPMENT OF THE LIVER}

Progenitor cells have the ability to differentiate (i.e., to acquire new morphology and functional characteristic) (126). The derivation of a large number of functional hepatocytes from stem cells remains a challenge. A better understanding of the molecular mechanisms that control hepatogenesis led to the development of strategies for directing the hepatic differentiation of stem cells in vitro. Recent advances in molecular genetics, molecular biology, and embryology made possible the identification of a series of signs generated during the development of an embryo. It is now known that embry- onic hepatic development happens due to a sequence of events that start during the gastrula phase of embryogenesis when the endoderm is initially segregated from the ectododerm and mesoderm. This segregation exposes the endoderm to several domains with distinct differentiation potential. The domain with hepatic competence initiates the primary hepatic induction after receiving signs from cardiac mesoderm and septum transversum mesenchyme. The response to those signs is the beginning of the primary hepatic program. In sequence, during the secondary hepatic induction, the immature liver invades the septum transversum. This invasion leads to a period of intense growing and differentiation originating a mature and functional organ. The genes that control those events, as well as the signs responsible for coordinating the liver formation during embryogenesis, have been extensively reviewed $(22,28,73,116,143,144)$.

ESCs and MSCs can be directed to differentiate towards a cell lineage in certain culture conditions. Specific drugs and growth factors that induce cell proliferation and differentiation during the development of an organism can be added to the medium in a stem cell culture. The mechanisms that control hepatogenesis are not fully understood, although important discoveries in this area allowed the proposition of many protocols aiming to direct the differentiation of MSCs $(55,113,122)$ and ESCs (2) into hepatocyte-like cells.

Studies involving the signaling from cardiac meso-

\section{MATURATION X TUMORIGENIC POTENTIAL}

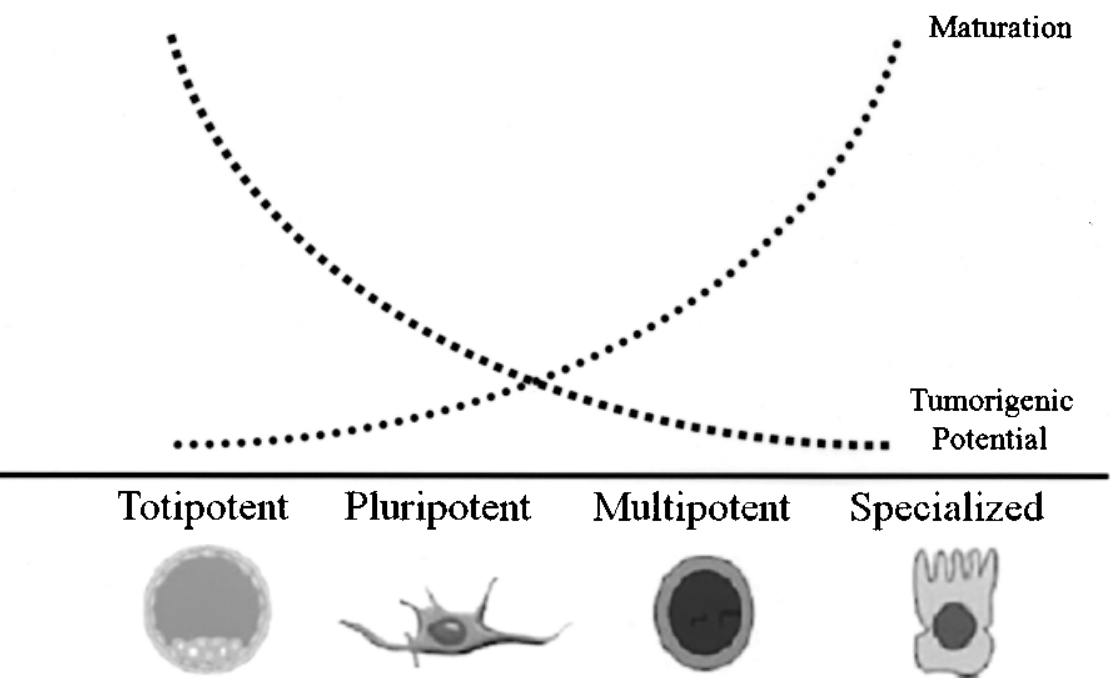

Figure 1. Stem cell types and liver regeneration. Although ESCs are immature, could be in vitro expanded and differentiated, they possess the highest tumorigenic potential. On the other hand, specialized cells like mature hepatocytes are poorly expanded. Liver oval cells, classified as multipotent stem cells, are lineage committed and less tumorigenic than pluripotent stem cells like mesenchymal cells. 
derm towards differentiation of hepatic progenitors of endodermic intestinal revealed that a group of molecules identified as fibroblast growth factors (FGF) was responsible for directing cell migration and hepatic differentiation (52). Other reports confirmed that FGF-4 inducts differentiation of MSC isolated from bone marrow $(55,112)$ and other tissues $(54)$ into hepatocyte-like cells.

The class of hepatocyte nuclear factor (HNF) proteins and their target genes were studied in embryoid bodies obtained from ESC. HNF3 factors are involved on nucleossomal organization of albumin gene as well as regulation of HNF4 promoter (member of receptor family of steroids hormones). HNF4- $\alpha$ is essential for morphological and functional differentiation of hepatocytes (94). In normal embryos, during the developing endoderm, HNF3- $\beta$ is expressed before HNF3- $\alpha$, being this sequence necessary for the expression of HNF3- $\alpha$. The expression of both factors simultaneously results in an antagonist effect, decreasing the transcriptional capacity of HNF3- $\beta$. The presence of insulin increases the expression of the regulator HNF3- $\beta$ and decreases HNF3$\alpha$, leading to a higher expression of HNF4 as well as other liver-specific genes whose products are important to glucose metabolism (29). Insulin is used in protocols to differentiate MSC into hepatocyte-like cells (112). The fact that insulin and other agents act in a coordinated way suggests that those factors should be added sequentially and respecting a specific timing (113).

Dexametasone is a synthetic corticosteroid used as supplement in primary hepatocyte culture. This chemical compound induces the expression of hepatocyte differentiated phenotype by suppressing cell division (45).

While many signs are involved in differentiation, others control the growth of the developing liver. Some pathways that control proliferation of the fetal liver involve hepatocyte growth factor (HGF). Beyond a potent mitogen, HGF influences cell migration and motility through transmembrane signals of tyrosine kinase by activation of its receptor, cMet. There is evidence that the path $\mathrm{HGF} / \mathrm{cMet}$ is responsible for the interaction between mesenchymal and epithelial cells during development. While HGF is expressed in mesenchymal cells, cMet is expressed in epithelial cells near the organs under development (28).

Oncostatin M (OSM) is a member of the interleukin6 cytokine family and seems to coordinate liver development and hematopoiesis in the fetus (77). The inclusion of nicotinamide, dimethyl sulfoxide (DMSO), and OSM in the culture medium was shown to have an important role in the development and differentiation of hepatocytes by enhancing in vitro maturation of fetal mouse liver cells when compared with conventional culture conditions (105).

Trichostatin A (TSA) is a fungistatic antibiotic and represents a specific class I and II histone deacetylase (HDAC) inhibitor (142). HDAC regulates gene expression (61) and it was proposed that TSA, accompanied by hepatogenic agents, would select the survival of differentiating cells towards the hepatocyte lineage by inducing apoptosis of nonhepatic differentiating cells (112).

Elucidation of interactions between chemical substances and specific factors linked to hepatic development may allow, in the near future, the obtention of in vitro hepatocytes differentiated from stem cells.

\section{HEPATOCYTE-LIKE CELLS}

Several studies reporting the generation of hepatocyte like-cells from adult derived human liver mesenchymallike cells (84) as well as from different stem cell types of extrahepatic human tissues have been published (Table 1). It is not certain whether any of these can function as mature hepatocytes with potential to be used for the treatment of liver diseases. Although it is a considerable step towards successful differentiation, knowledge concerning liver organogenesis and also biology of stem cells has yet to define some crucial steps in order to achieve a feasible protocol to differentiate a stem cell into functional and transplantable hepatocytes.

The development of adequate culture conditions, dosage and combination of cytokines and growth factors, as well as their sequence exposure is crucial for directing the hepatic differentiation of stem cells in vitro. A good example would be the study of Snykers and colleagues: when hepatogenic factors were added in a sequential manner, reflecting their temporal expression during in vivo hepatogenesis, instead of a cocktail kind of exposure, the cells presented enhanced hepatic differentiation (112).

The source of stem cells is an important issue concerning transplantable hepatocyte-like cells. Autologous transplantation would be more preferable than allogeneic or embryonic once it eliminates the risk of rejection and represents a feasible source of cells with no ethical implications. ESC pluripotency and unlimited selfrenewal capacity (82) corroborate with reports showing their potential in generating hepatocyte-like cells (2). However, it seems that the successful use of a given cell source will depend on future research and the overcome of technical challenges.

An adult hepatocyte phenotype was not reached using human adipose tissue-derived cells (122). In another study, after differentiation of human adipose tissue stem cells into hepatocyte-like cells, it was examined whether the generated hepatocytes were therapeutically applicable by transplantation into $\mathrm{CCl}_{4}$-injured mouse. The hepatocytes were incorporated into host livers and in those mice some liver functions were improved, indicating that they might be applicable for transplantation (8). 
Table 1. Differentiation of Human Stem Cell Populations Into Hepatocyte-Like Cells

\begin{tabular}{|c|c|c|c|c|c|}
\hline \multirow[b]{3}{*}{ Stem Cell Type } & \multicolumn{2}{|c|}{ Culture Conditions } & \multirow{2}{*}{\multicolumn{2}{|c|}{ Characterization }} & \multirow[b]{3}{*}{ Key Ref. } \\
\hline & \multirow{2}{*}{$\begin{array}{l}\text { Predifferentiation } \\
\text { Procedure }\end{array}$} & \multirow{2}{*}{$\begin{array}{l}\text { Hepatogenic } \\
\text { Factors }\end{array}$} & & & \\
\hline & & & Phenotypical & Functional & \\
\hline Embryonic & $\begin{array}{l}\text { Up to } 80 \% \text { confluent } \\
\text { cultures placed in cul- } \\
\text { ture medium supple- } \\
\text { mented with KOSR } \\
\text { and Activin A. }\end{array}$ & $\begin{array}{l}\text { FGF-4, HGF, OSM, } \\
\text { and dexamethasone; } \\
\text { sequential exposure. }\end{array}$ & $\begin{array}{l}\text { Generation of } 70 \% \text { of } \\
\text { cells with hepatocyte } \\
\text { morphology express- } \\
\text { ing a repertoire of } \\
\text { characteristic genes } \\
\text { and hepatocyte-spe- } \\
\text { cific markers analyzed } \\
\text { by immunofluores- } \\
\text { cence and RT-PCR. }\end{array}$ & $\begin{array}{l}\text { Cells displayed hepa- } \\
\text { tocyte-like functions: } \\
\text { ability to store glyco- } \\
\text { gen, uptake and re- } \\
\text { lease indocyanine } \\
\text { green (ICG), and albu- } \\
\text { min secretion. }\end{array}$ & 2 \\
\hline \multirow[t]{2}{*}{ Adipose tissue } & $\begin{array}{l}\text { Culture of adherent } \\
\text { passage } 2 \text { cells at } 85 \% \\
\text { confluency in serum- } \\
\text { deprived medium sup- } \\
\text { plemented with EGF } \\
\text { and bFGF were used } \\
\text { for differentiation } \\
\text { assay. }\end{array}$ & $\begin{array}{l}\text { HGF, bFGF, } \\
\text { ITS+premix, OSM, } \\
\text { nicotinamide, dexa- } \\
\text { methasone; two step } \\
\text { protocol. }\end{array}$ & $\begin{array}{l}\text { Morphology and de- } \\
\text { tection of hepatocyte- } \\
\text { specific markers by } \\
\text { RT-PCR and immuno- } \\
\text { histochemistry showed } \\
\text { expression of albumin } \\
\text { and CYP isozymes. } \\
\text { Hepatogenic differen- } \\
\text { tiation was successful, } \\
\text { although the hepato- } \\
\text { cyte adult phenotype } \\
\text { was not reached. }\end{array}$ & Not performed. & 122 \\
\hline & $\begin{array}{l}\text { Passage } 2 \text { cultures of } \\
\text { adherent cells in cul- } \\
\text { ture medium supple- } \\
\text { ment with FBS fol- } \\
\text { lowed by isolation of } \\
\text { the CD105 positive. }\end{array}$ & $\begin{array}{l}\text { FGF1, FGF4, HGF, } \\
\text { OSM, dexametha- } \\
\text { sone; sequential expo- } \\
\text { sure. }\end{array}$ & $\begin{array}{l}\text { RT-PCR, immuno- } \\
\text { staining, and Western } \\
\text { Blot detection of hepa- } \\
\text { tocyte-specific mark- } \\
\text { ers. }\end{array}$ & $\begin{array}{l}\text { The analysis of glyco- } \\
\text { gen storage, albumin } \\
\text { secretion, and ammo- } \\
\text { nia clearance from cul- } \\
\text { ture media revealed } \\
60-85 \% \text { functional } \\
\text { and transplantable he- } \\
\text { patocytes. }\end{array}$ & 8 \\
\hline Monocytes & $\begin{array}{l}\text { Adherent cells were } \\
\text { cultured for } 6 \text { days in } \\
\text { culture medium sup- } \\
\text { plemented with human } \\
\text { serum, } \beta \text {-mercaptoeth- } \\
\text { anol, macrophage col- } \\
\text { ony stimulating factor, } \\
\text { and human interleu- } \\
\text { kin-3. }\end{array}$ & $\begin{array}{l}\text { FGF-4; two-step pro- } \\
\text { tocol. }\end{array}$ & $\begin{array}{l}\text { Cells presented hepa- } \\
\text { tocyte-like morpho- } \\
\text { logic characteristics } \\
\text { and expression of } \\
\text { liver specific proteins. }\end{array}$ & $\begin{array}{l}\text { In vitro metabolic } \\
\text { functions (albumin se- } \\
\text { cretion, urea produc- } \\
\text { tion, lactate formation, } \\
\text { lactate dehydroge- } \\
\text { nase, and aspartate } \\
\text { transaminase release) } \\
\text { were shown to be in } \\
\text { part comparable with } \\
\text { those of primary hu- } \\
\text { man hepatocytes. }\end{array}$ & 103 \\
\hline Bone marrow & $\begin{array}{l}\text { Culture of adherent } \\
\text { passage } 2 \text { cells at } 85 \% \\
\text { confluency in serum- } \\
\text { deprived medium sup- } \\
\text { plemented with EGF } \\
\text { and bFGF were used } \\
\text { for differentiation } \\
\text { assay. }\end{array}$ & $\begin{array}{l}\text { HGF, bFGF, } \\
\text { ITS+premix, OSM, } \\
\text { nicotinamide, dexa- } \\
\text { methasone; sequential } \\
\text { exposure. }\end{array}$ & $\begin{array}{l}\text { Morphology and detec- } \\
\text { tion of hepatocyte-spe- } \\
\text { cific markers revealed } \\
\text { expression of albumin } \\
\text { and CYP isozymes. } \\
\text { Hepatogenic differen- } \\
\text { tiation was successful, } \\
\text { although the hepato- } \\
\text { cyte adult phenotype } \\
\text { was not reached. }\end{array}$ & Not performed. & 122 \\
\hline
\end{tabular}


Table 1. Continued

\begin{tabular}{|c|c|c|c|c|c|}
\hline \multirow[b]{3}{*}{ Stem Cell Type } & \multicolumn{2}{|c|}{ Culture Conditions } & \multirow{2}{*}{\multicolumn{2}{|c|}{ Characterization }} & \multirow[b]{3}{*}{ Key Ref. } \\
\hline & \multirow{2}{*}{$\begin{array}{l}\text { Predifferentiation } \\
\text { Procedure }\end{array}$} & \multirow{2}{*}{$\begin{array}{c}\text { Hepatogenic } \\
\text { Factors }\end{array}$} & & & \\
\hline & & & Phenotypical & Functional & \\
\hline & $\begin{array}{l}\text { Fourth passage culture } \\
\text { of adherent cells at } \\
100 \% \text { confluency was } \\
\text { used for differentia- } \\
\text { tion assay. }\end{array}$ & $\begin{array}{l}\text { FGF-4, HGF, ITS, } \\
\text { dexamethasone, TSA } \\
\text { (on the 6th day of ex- } \\
\text { posure); cocktail and } \\
\text { sequential exposure. }\end{array}$ & $\begin{array}{l}\text { Cocktail: Acquisition } \\
\text { of an epithelial mor- } \\
\text { phology and immuno- } \\
\text { fluorescence for hepa- } \\
\text { tocyte-specific } \\
\text { markers was per- } \\
\text { formed. Cells ex- } \\
\text { pressed hepatocyte } \\
\text { markers comparable to } \\
\text { their expression pat- } \\
\text { tern during in vivo } \\
\text { hepatogenesis. }\end{array}$ & $\begin{array}{l}\text { Albumin secretion, } \\
\text { urea production, and } \\
\text { CYP-dependent activ- } \\
\text { ity assay and acquired } \\
\text { functional maturation. }\end{array}$ & 112 \\
\hline & & & $\begin{array}{l}\text { Sequential exposure: } \\
\text { A homogeneous popu- } \\
\text { lation of epithelioid } \\
\text { cells was obtained and } \\
\text { immunofluorescence } \\
\text { for hepatocyte-specific } \\
\text { markers was per- } \\
\text { formed. About } 70 \% \text { of } \\
\text { cells expressed hepato- } \\
\text { cyte markers compara- } \\
\text { ble to their expression } \\
\text { pattern during in vivo } \\
\text { hepatogenesis. }\end{array}$ & $\begin{array}{l}\text { Albumin secretion, } \\
\text { urea production, and } \\
\text { CYP-dependent activ- } \\
\text { ity assay and acquired } \\
\text { functional maturation } \\
\text { more prominent than } \\
\text { the cells under cock- } \\
\text { tail exposure. }\end{array}$ & \\
\hline
\end{tabular}

Adult stem cells represent a heterogeneous population (7), and therefore only a small proportion of cells are capable of differentiation into hepatocyte-like cells. It was observed that a small percentage of cells after differentiation express characteristic liver markers such as albumin, transferring, and HNF3- $\beta$. In addition, those cells have much lower enzymatic competence when compared to primary hepatocyte culture (45). To avoid heterogeneity of cells, an isolation step can be added before the differentiation procedure, such as selection of CD105-positive cells (8).

Peripheral blood would be an interesting readily accessible source of cells for generation of hepatocyte-like cells. It was reported that human peripheral blood monocytes can differentiate into hepatocyte-like cells (146) with some in vitro metabolic functions comparable to those of primary human hepatocytes (103).

Although many sources of cells have been investigated, the question of whether these are the best sources of stem cells for cell therapy in patients with liver diseases remains unclear.

\section{PRECLINICAL STUDIES}

The majority of the experimental work published at this moment has focused on the transplantation of stem cells without hepatocyte differentiation protocols. Most studies have also performed cell transplantation by intravenous systemic infusions. The first parameter to be analyzed is whether stem cells can migrate to the targeted tissue or organ. A recent work showed that, in noninjured rats, the majority of the cells intravenously infused were trapped inside the lungs and only small numbers actually reached the arterial system acutely (33). Despite this observation, several studies with different experimental models of hepatic diseases have demonstrated that, even when systemically infused, stem cells can migrate, engraft, and promote functional recovery of the liver after cell therapy (Table 2).

This was found in mice knockout for fumarylacetoacetate hydrolase (Fah) after the transplantation of bone marrow cells, with a reduction in levels of transaminases and bilirubin $(63,130)$, as well as in mice with 
$\mathrm{CCl}_{4}$-induced hepatic injury, which showed a rise in serum albumin and decreased prothrombin time $(51,91)$, and in a model of injury by partial hepatectomy and dietylnitrosamine (DEN), showing a reduction in aspartate transaminase (AST), alanine transaminase (ALT), hyaluronic acid, and laminin (147). A rise in the production of albumin was also demonstrated by our group after therapy with bone marrow cells in a mice model of chronic infection by Schistosoma mansoni (89).

The mechanisms underlying the therapeutic effects of stem cells transplantation in liver diseases could involve transdifferentiation, cell fusion, or paracrine bystander actions (Fig. 2). It has been suggested that the presence, severity, and type of hepatic injury could be important in regulating the plasticity of stem cells (71). With the increasingly data available, transdifferentiation is now known to not occur, or only in very small frequency, leading the therapeutic effects to paracrine actions or cell fusion. In the following sections, we detail the main findings with stem cell therapies using different cell types, such as bone marrow cells, mesenchymal stem cells, cord blood cells, and intrahepatic progenitors, as well as therapy with growth factors in experimental models of liver diseases.

\section{Bone Marrow Cells}

Autologous transplantation of bone marrow cells is as an interesting option in regenerative medicine because it is a safe procedure with extensive clinical experience. The protocols used do not involve cell culture and therefore may be simpler and less expensive. However, transplanted cells in these cases do not represent a single purified lineage of cells, being a heterogenous cell population in which stem cells represent only a small fraction.

The relationship between liver and bone marrow begins in the fetal liver, a major site of hematopoiesis (92). Furthermore, there is evidence that the inverse process can occur in the adult liver. Hepatocytes carrying $\mathrm{Y}$ chromosome were detected in livers of female recipients of bone marrow transplantation from male donors (127). Therefore, investigating the therapeutic potential of bone marrow cells has been a matter of studies with several experimental models of hepatic diseases.

Lagasse and colleagues worked with the experimental model of type I tyrosinemia, in which mice are deficient for Fah, a crucial enzyme in the final steps of tyrosine metabolism, and therefore this is associated with increased hepatocyte death (63). Authors demonstrated that the intravenous infusion of bone marrow cells from wild-type donors increased survival rates through the correction of the metabolic disorder. Transplanted bone marrow cells gave rise to nodules of hepatocytes $\mathrm{Fah}^{+/+}$, repopulating the liver with bone marrow-derived hepatic cells. In this model, donor-derived hepatocytes accounted up to $30 \%$ of the total liver cells. This high

Table 2. Effects of Cell or Growth Factor Therapy in Experimental Models of Hepatic Diseases

\begin{tabular}{ll}
\hline & \multicolumn{1}{c}{ Effects Reported } \\
\hline $\begin{array}{l}\text { Hepatic alterations } \\
\text { Fibrosis }\end{array}$ & Reduced $(1,15,31,67,89,91,98,106,107,137,145,147) ;$ NS (17,91) \\
Inflammation & Reduced $(91,147)$ \\
Hepatocyte apoptosis & Reduced $(129)$ \\
Donor-derived hepatocytes & Identified $(9,14,17,26,50,51,60,63,85,89,91,98,106,107,129,130,133,136$, \\
& $145,147)$ \\
Mechanism suggested & Cell fusion $(14,130,133,136) ;$ Transdifferentiation $(51,60,85)$ \\
TGF- $\beta$ levels/expression & Reduced $(31,89,106-108,137)$ \\
HGF levels/expression & Increased $(140) ; N S(106,107)$ \\
Metalloproteinases levels/expression & Increased $(98,106,107)$ \\
Expression of genes related to hepatic regeneration & Increased $(98,129)$ \\
Serum bilirubin & Reduced $(14,60,63,124,130,136,145) ; N S(31,147)$ \\
Serum albumin & Increased $(1,60,91,106,107) ;$ NS $(17)$ \\
Prothrombin time & Reduced $(51)$ \\
Serum transaminases & Reduced $(14,31,51,60,63,91,108,124,129,136,145,147) ; N S(1,9,17)$ \\
Portal pressure & Reduced $(67)$ \\
Mortality & Reduced $(9,26,60,106,107,124,129,140,145) ;$ NS $(20,147)$ \\
\hline
\end{tabular}




\section{CELL THERAPY IN CHRONIC LIVER DISEASES}

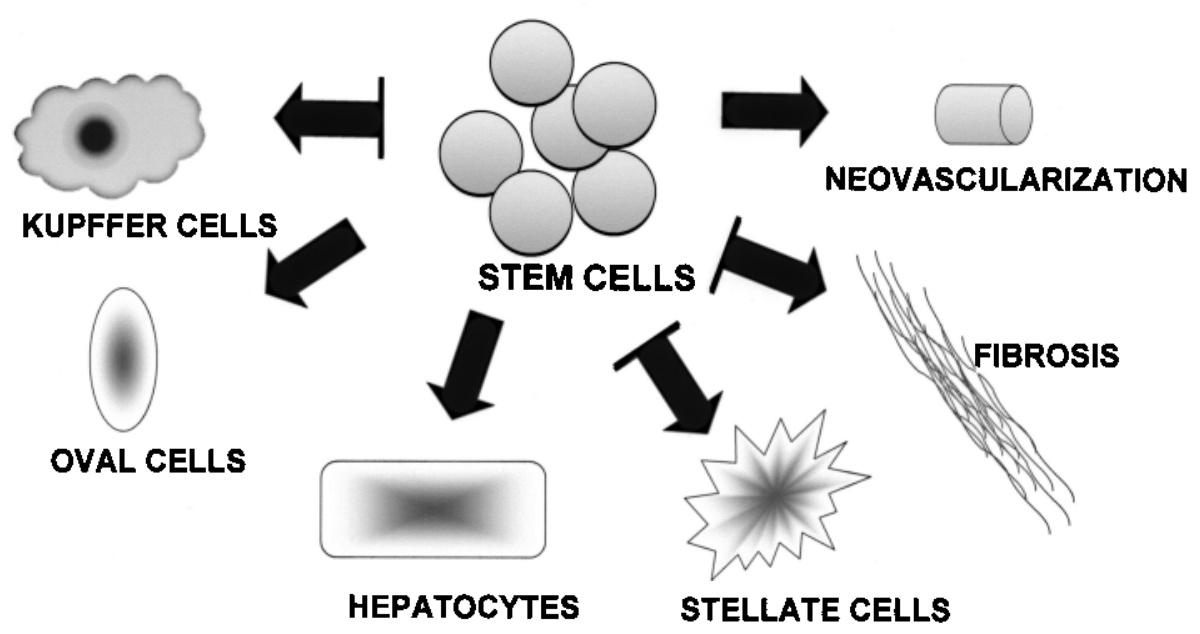

Figure 2. Possible mechanisms of action of stem cells in chronic liver diseases. For liver tissue repair, stem cells may act by one or multiple mechanisms, directly or indirectly through the secretion of molecules, such as soluble mediators and metalloproteinases. These include the formation of new blood vessels in ischemic areas, the degradation of fibrosis directly or by downmodulation of stellate and Kupffer cells and of profibrogenic factors such as TGF- $\beta$, and the generation of new hepatocytes directly (by fusion or transdifferentiation), by stimulation of hepatocyte proliferation (e.g., through the release of HGF) or by the increase in oval cell numbers.

level of repopulation was achieved because of the high selective pressure favoring the transplanted cells found in this model. These results were confirmed by Vassilopoulos et al. (130) and Wang et al. (133). In these two studies, authors concluded that the main mechanism involved in the generation of bone marrow-derived hepatocytes was cell fusion. Similar results were found in mice transplanted with purified myelomonocytic cells and bone marrow-derived macrophages $(14,136)$.

The contribution of bone marrow cells in reducing liver fibrosis has also been investigated with positive results achieved in the majority of the studies; however, high levels of liver repopulation by transplanted cells were not demonstrated. An extensively studied experimental model is $\mathrm{CCl}_{4}$-induced liver fibrosis. In this model, fibrogenesis occurs in a dose-dependent and time-dependent manner in rats and mice (123). Jang and colleagues demonstrated that a population of bone marrow purified stem cells can transdifferentiate into hepatocytes in vitro and in vivo, contrary to the results found in $\mathrm{Fah}^{-/}$mice (51). Transplantation of bone marrow cells also promoted a functional improvement in mice with acute injury caused by $\mathrm{CCl}_{4}$. Sakaida and colleagues observed improvement in hepatic function, re- duction in fibrosis percentage and enhanced survival rates in mice treated with intravenously injection of bone marrow cells after $\mathrm{CCl}_{4}$-induced acute injury. The authors suggested that transdifferentation into hepatocytes had occurred (107). Fibrosis reduction was reported in rats with $\mathrm{CCl}_{4}$-induced liver fibrosis after bone marrow mononuclear cells transplantation (15). A reduction in liver fibrosis was also demonstrated in the experimental model of hepatectomy and dimetylnitrosamine administration $(145,147)$ and in hepatic fibrosis caused by chronic infection by Schistosoma mansoni (89).

The correlation of fibrosis reduction and lower levels of TGF- $\beta$, a cytokine that plays a key role in fibrogenesis, was also demonstrated after cell therapy $(31,89)$. Corroborating those findings, levels of matrix metalloproteinases, which are enzymes responsible for matrix degradation, were found to be elevated following therapy in some studies $(98,106,107)$. Increased expression of matrix metalloproteinases was also reported in bone marrow-derived cells found in livers of chimeras during the fibrosis resolution phase (46).

Our group studied the model of hepatic cirrhosis induced in mice by chronic administration of $\mathrm{CCl}_{4}$ associated with ethanol and the model of periportal fibrosis 
induced by chronic infection by Schistosoma mansoni. The presence of hepatocytes of donor origin in the liver was detected 2 months after the treatment. It was observed that the infusion of bone marrow mononuclear cells promoted a reduction in fibrosis and improved albumin production (89). Dahlke reported that the infusion of bone marrow cells did not result in a functional benefit in terms of survival rates in the experimental model of acute hepatic failure induced by retrorsine and $\mathrm{CCl}_{4}$ (20).

The ability of bone marrow cells to give rise to hepatic nonparenchymatous cells involved in the modulation of liver fibrosis has been reported with conflicting conclusions. Duffield demonstrated that bone marrowderived macrophages played an important role in the resolution of fibrosis caused by $\mathrm{CCl}_{4}$ (27). This seems to occur through an increased production of MMP-13 (30). On the other hand, some recent studies have pointed to a profibrogenic potential of bone marrow cells transplantation, because it has been demonstrated that hematopoietic stem cells have the ability to differentiate into stellate cells after transplantation (78). Hepatic stellate cells play a key role in liver fibrogenesis, due to its ability in differentiating into myofibroblasts and secrete components of extracelular matrix. Other studies reported the presence of myofibroblasts derived from bone marrow contributing for fibrogenesis (57, 104). Asawa and colleagues also showed the potential of bone marrow cells in converting into cells with a fibroblast and myofibroblast phenotype in an early phase of periductular fibrosis (6). These results came from studies with bone marrow chimeras and the relevance of those findings in the scope of the possible alterations seen after transplantation has yet to be clarified.

Because the participation of progenitor cells is physiologically required when hepatocyte proliferation is blocked or in the setting of extensive injuries, stem cell transplantation is also a promise in the treatment of massive hepatic necrosis. This was evaluated in the experimental model of acute liver failure induced by acetaminophen in rats. In this study, bone marrow mononuclear cells injection into the portal vein $24 \mathrm{~h}$ after the drug administration promoted a significant reduction in mortality and in liver necrosis. However, liver repopulation by donor cells was not evaluated in this study (9).

Most of the studies described above point out for a therapeutic effect of bone marrow cell transplantation in hepatic diseases. However, which cell populations would be responsible for the reported effects and the precise mechanisms involved are still matter of discussion. The results found may be diverse due to the particularities and differences between the experimental models studied or the methods used in the investigations. It is possible that the contribution of different mechanisms, like cell fusion and paracrine effects may occur depending on the cell populations transplanted and also on the type of injury occurring in the liver.

\section{Mesenchymal Stem Cells}

A small fraction of the bone marrow stromal cells called mesenchymal stem cells have been a matter of study in regenerative medicine. Their pluripotency and therapeutic effects have been well described in different models of degenerative diseases (16). These cells physiologically give support to hematopoiesis by cell contact and secretion of a number of cytokines and growth factors (23). They are characterized by being plate adherent, capable of self-renewing, negative for hematopoietic cell markers and having potential of differentiation into mesenchymal lineages. Besides bone marrow, a variety of tissues have been used as sources of mesenchymal stem cells, like adipose tissue, umbilical cord blood, and dental pulp $(42,54,119)$. It has been shown that cultured mesenchymal stem cells can differentiate into a hepatocyte phenotype under appropriate conditions, indicating the potential use of these cells in hepatic diseases (90). In addition to their pluripotency, mesenchymal stem cells have been shown to have immunomodulatory properties and to be able to secrete a number of factors involved in tissue regeneration and reduction of inflammation (23,101). Mesenchymal stem cells can also be regulated by other cells. Recent studies demonstrated that mesenchymal stem cells cocultured with hepatic stellate cells had enhanced proliferation and differentiation into hepatocyte-like cells $(24,66)$.

It has been shown that mesenchymal stem cells can migrate and engraft into injured liver. The administration of mesenchymal stem cells marked with iron particles in the portal vein of rats with hepatic injury induced by administration of $\mathrm{CCl}_{4}$ allowed the demonstration, through magnetic resonance analysis, that these cells remained in the liver up to 12 days after the injection (12). The therapeutic potential of bone marrow mesenchymal stem cells was first tested in a model of acute liver injury in mice treated with $\mathrm{CCl}_{4}$ (31). The syngeneic transplantation of mesenchymal stem cells immediately after the administration of $\mathrm{CCl}_{4}$ reduced the hepatic damage, the development of fibrosis, and accelerated liver regeneration. It was observed a correlation between the reduction of collagen and the levels of TGF- $\beta$ in the animals treated with mesenchymal stem cells immediately after the administration of $\mathrm{CCl}_{4}$. Hepatic cells with $\mathrm{Y}$ chromosome were found in the liver of the female mice transplanted with mesenchymal cells of male donors. These cells appeared in small numbers, showing low levels of repopulation. Although in this model positive results 
were found when the cells were injected immediately after the injury induction, it was not observed any benefit when the cells were injected 1 week later.

Bone marrow mesenchymal stem cell transplantation was also beneficial in models of hepatic fibrosis in rats $(1,145)$. Zhao and colleagues induced liver fibrosis by administration of either $\mathrm{CCl}_{4}$ or dimetylnitrosamine (DMN) and the animals were injected with bone marrow mesenchymal cells intravenously at different time points (145). The authors observed a reduction in mortality, weight, collagen deposition, and an improvement in biochemical parameters of liver function. The sooner the transplantation occurred, the better were the therapeutic effects found. In another study, mesenchymal stem cells injected into the portal vein were able to differentiate into hepatocytes, reduce fibrosis, and restore hepatic function (147).

In opposition to the results described above, a recent study by Carvalho and colleagues demonstrated that mesenchymal stem cells injection into the portal vein of rats with liver cirrhosis induced by $\mathrm{CCl}_{4}$ and ethanol did not reduce hepatic fibrosis or promote any improvement in parameters of liver function (17). Oyagi and colleagues also failed to demonstrate benefits in transplantation of mesenchymal stem cells in rats with $\mathrm{CCl}_{4}{ }^{-}$ induced liver fibrosis (91). However, the authors pointed out that transplantation of mesenchymal stem cells cultured in the presence of the hepatocyte growth factor (HGF) was beneficial, promoting a significant improvement in serum albumin and transaminases, and also a reduction in fibrosis (91).

Most of the studies with mesenchymal stem cells showed a poor liver repopulation, although most were associated with benefic results. This was also seen in an experimental model of acute liver failure (60). The possibility of occurrence of paracrine action was evaluated in a recent work with the experimental model of acute liver failure induced by D-galactosamine in rats. After hepatic injury induction, rats that received mesenchymal stem cell-conditioned medium intravenously had reduced mortality levels. This was associated with a $90 \%$ reduction in hepatocytes apoptosis and a threefold increase in proliferation of hepatocytes, suggesting that the therapy had enhanced liver endogenous regeneration programs (129).

The beneficial results found in the majority of the experimental studies with mesenchymal stem cells in liver diseases encourage clinical studies. However, there is still concern in respect to genetic and chromosomic alterations that could be found in cultured and expanded cells (102) and therefore cytogenetic control is needed for discharging the risk for neoplastic transformation before clinical use.

\section{Umbilical Cord Blood Cells}

The umbilical cord blood is a source of young hematopoietic and mesenchymal stem cells that therefore could have advantages in plasticity upon other types of adult stem cells for regenerative medicine. A major problem for clinical use is that availability of these cells for autologous transplants requires the presence of a cord blood banking. In case of heterologous transplants, rejection could occur and immunossupression could be needed. However, it has been shown that cord blood contains cells with the potential of differentiation in hepatocytes in vitro, indicating a possible use in the treatment of liver diseases $(47,53)$. Kang and colleagues also demonstrated in vitro differentiation of cord blood mesenchymal stem cells cultured in the presence of fibroblast growth factor-4 (FGF-4) and HGF (54).

The experimental work with cord blood cells has been based upon the xenotransplantation of human cells into mice or rats, usually of immunodeficient lineages. Di Campli and colleagues investigated the therapeutic potential of human cord blood cells in a murine model of hepatic injury caused by administration of allyl alcohol to immunodeficient NOD/SCID mice. The cord blood mononuclear cells were injected intraperitoneally after induction of hepatic injury (26). The authors observed that the transplanted cells differentiated into hepatocytes and promoted an improvement in liver function and in survival rates. Similar results were obtained by Tang and colleagues, in a model of acute liver failure induced by carbon tetrachloride in rats. In this study, the animals that received cord blood cells intraperitoneally 3 days after the administration of $\mathrm{CCl}_{4}$ had a significant improvement in liver function and survival rates (124). Histological analysis of the liver after 5 days demonstrated reduced numbers of inflammatory cells and necrosis area. Functional donor-derived hepatocytes expressing albumin mRNA were found in sublethally irradiated NOD/SCID mice transplanted with human cord blood cells $(50,83)$. Furthermore, Piscaglia and colleagues demonstrated that the infusion of cord blood cells in rats with liver injury caused by administration of allyl alcohol improved liver regeneration. By microarray analysis, the authors demonstrated that cell therapy promoted an enhancement in the expression of 256 genes and a reduction in 149 genes. The upregulated genes included those involved in cell proliferation, differentiation, adhesion, cell migration, and oval cell activation (98). In an experimental model of hepatitis induced by D-galactosamine, improvement in histological damage and liver function reduction was observed when human umbilical cord blood mononuclear cells were intraportally administered in rats (3). 


\section{Intrahepatic Stem Cells}

Intrahepatic stem cells would be, in theory, the ideal cells for the treatment of liver diseases because of their lineage commitment. However, difficulties in isolation and culture have limited their use to only few experimental studies. Oval cells are well-characterized intrahepatic stem cells, with the potential of differentiation into hepatocytes and cholangiocytes (96). Wang and colleagues investigated the regenerative potential of oval cells in $\mathrm{Fah}^{-/}$mice. Oval cells were isolated from livers of wild-type mice and injected into the spleen of $\mathrm{Fah}^{-1-}$ mice. The injection of oval cells was more efficient than treatment with mature hepatocytes (132). In a model of hepatic injury caused by partial hepatectomy associated with administration of monocrotaline, a drug that inhibits the proliferation of hepatocytes, wild-type animals received transplantation of oval cells transfected with a vector carrying $\alpha 1$-antitripsin and green fluorescent protein genes (GFP) (115). It was observed the presence of hepatic cells expressing those markers in about $40-50 \%$ of the total parenchyma 18 weeks after transplantation.

\section{Growth Factors}

A possible alternative to the transplantation of stem cells in liver diseases is the activation of resident stem cells or the recruitment of extrahepatic stem cells achieved through the administration of growth factors. Granulocyte-colony stimulating factor (G-CSF) is a cytokine that mobilizes hematopoietic stem cells to the periphery and a large clinical experience has been built due to its use in hematologic diseases. In addition to its role in bone marrow stem cells recruitment, it is known that oval cells express G-CSF receptors and therefore a direct action of this cytokine in the intrahepatic progenitors has been postulated (97). An increased proliferation of intrahepatic progenitor cells was reported in patients with steato-hepatitis 7 days after G-CSF administration (117). Furthermore, treatment with G-CSF led to a significantly increased oval cell reaction following partial hepatoctomy and acetylaminofluorene administration in rats, in addition to migration of bone marrow progenitors to the liver (97).

Treatment with G-CSF is also associated with improvement in liver injuries in some experimental studies. Quintana-Bustamante and colleagues demonstrated that the administration of G-CSF in mice with liver injuries whether induced by $\mathrm{CCl}_{4}$ or due to Fah deficiency improved the generation of bone marrow-derived hepatocytes (100). The administration of G-CSF in both acute and chronic liver injuries induced by $\mathrm{CCl}_{4}$ in mice promoted improvement in liver injuries by increased regeneration and cell proliferation, correlating with the presence of hepatocytes derived from mobilized cells (140).
Hepatocyte growth factor (HGF) may also have a role in the treatment of liver diseases. In a model of hepatic fibrosis induced by bile duct ligation in mice, gene therapy with a plasmid containing HGF gene caused an improvement in hepatic injury and reductions in fibrosis, production of TGF- $\beta$, and in alterations of bile duct epithelium basal membrane (137).

Insulin-like growth factor (IGF-1) stimulates the production of HGF and inhibits the production of TGF- $\beta$ by hepatic stellate cells (108). The therapeutic potential of IGF-1 was tested in the model of $\mathrm{CCl}_{4}$-induced liver cirrhosis in rats (67). In this study, a reduction in collagen amounts and portal pressure were seen in cirrhotic animals treated with this factor.

\section{CLINICAL STUDIES IN CELL THERAPY FOR LIVER DISEASES}

After the publications of studies with transplants of bone marrow mononuclear and mesenchymal cells in animals with hepatic cirrhosis, some investigators evaluated the potential of cell therapy in patients with hepatic cirrhosis in phase I safety and feasibility studies. Therefore, most of the published data came from uncontrolled studies.

Some studies have assessed the safety of using high doses of G-CSF to mobilize stem cells to the periphery in patients with advanced liver disease, as well as the efficacy of this protocol in providing adequate numbers of cells for further transplantation. Other studies have used bone marrow aspiration and further purification of the cell populations of interest. At this moment, those have been total mononuclear cells, CD $34^{+}$cells, CD133 ${ }^{+}$ cells, or mesenchymal stem cells. The types of protocol used are described in Table 3.

Gaia et al. evaluated the safety and feasibility of the isolated mobilization of bone marrow mononuclear cells in eight patients with terminal stage hepatic cirrhosis, submitted to the application of G-CSF. The mobilization of $\mathrm{CD}_{3} 4^{+}$bone marrow cells was observed in all of the patients after the application of G-CSF, which was well tolerated and free of adverse events. The Child-Pugh score decreased two or more points in three patients, increased in one patient, while having no alterations (or decreased fewer than 2 points) in three patients. The MELD score decreased from an average pretreatment value of 17.5 (variation of 11-20) to 14.5 (variation of 9-20) at the end of follow-up (37).

Yannaki et al. included two patients with decompensated liver cirrhosis in the protocol of the study. The patients were submitted to one or three rounds of G-CSF and, afterwards, the mobilized cells were collected and infused via a peripheral vein. The procedure was well tolerated and the authors reported an improvement in Child-Pugh and MELD scores after 12 months (139). 
Table 3. Types of Protocols Utilized in the Clnical Studies of Stem Cells in Liver Diseases

\begin{tabular}{lcl}
\hline Study Population & Type of Protocol Ref. \\
\hline
\end{tabular}

Two patients with cirrhosis

Eight patients with cirrhosis

Five patients with cirrhosis

Nine patients with cirrhosis

Ten patients with cirrhosis

Four patients with decompensated cirrhosis

Four patients with decompensated cirrhosis

Thirty patients with cirrhosis

Nine patients with alcoholic liver cirrhosis

Six patients with hepatic malignant lesions

Thirteen patients with hepatic malignant lesions

G-CSF, granulocyte-colony stimulating factor.
Noncontrolled study; G-CSF in high doses associated with infusion of

139 $\mathrm{CD} 34^{+}$cells (obtained from peripheral blood) through the peripheral vein $-2.3-4 \times 10^{6} / \mathrm{kg}$ cells for each patient.

Noncontrolled study; Mobilization of CD34 ${ }^{+}$cells with G-CSF.

Noncontrolled study; Infusion of CD $34^{+}$cells obtained from peripheral blood after mobilization with G-CSF; Infusion through the hepatic artery $(n=2)$ and portal vein $(n=3)$; Infusion of $1 \times 10^{6}$ to $2 \times 10^{8}$ cells/ patient

Noncontrolled study; Infusion of mononuclear cells obtained from bone marrow aspiration; Infusion through peripheral vein; Infusion of $5.20 \pm 0.63 \times 10^{9}$ cells/patient

Noncontrolled study; Infusion of mononuclear cells obtained from bone marrow aspiration; Infusion through hepatic artery; Infusion of at least $1 \times 10^{8}$ cells/patient

Noncontrolled study; Infusion of cultured mesenchymal cells obtained from bone marrow aspiration; Infusion through peripheral vein; Mean of $3.173 \times 10^{6}$ cells/patient

Noncontrolled study; Infusion of $\mathrm{CD} 34^{+}$cells obtained from bone marrow aspiration; Infusion through hepatic artery; Infusion of 3-10 $\times 10^{6}$ cells/patient

Controlled randomized study; Infusion of mononuclear cells obtained from bone marrow aspiration; Infusion through hepatic artery; Infusion of at least $1 \times 10^{8}$ cells/patient

Noncontrolled study; Infusion of expanded CD $34^{+}$cells obtained from peripheral blood after mobilization with G-CSF; Infusion of $2.3 \times 10^{8}$ cells/patient through hepatic artery

Nonrandomized controlled study; Infusion of purified CD $133^{+}$cells obtained from bone marrow aspiration; Infusion of at least $2.4 \backslash \mathrm{mul} ; \backslash 10^{6}$ cells/patient through nonoccluded portal branches after embolization

Nonrandomized controlled study; Infusion of purified CD $133^{+}$cells obtained from bone marrow aspiration; Infusion of at least $2.4 \times 10^{7}$ cells/ patient through nonoccluded portal branches after embolization of cell infusion. Three of the five patients presented improvement in serum bilirubin levels and four patients improved their albumin levels during the observation period of 60 days (41). In a subsequent publication, the same authors reported the follow-up results of the five patients during a period of $12-18$ months. All the patients remained without complications or adverse events related to the procedure and the partial improvement of liver function lasted approximately 12 months (64).

A recently published study by Pai et al. evaluated the feasibility and safety of autologous transplantation of in vitro expanded $\mathrm{CD}_{3} 4^{+}$cells into nine patients suffering from alcoholic liver cirrhosis. To be included in the them via hepatic artery. No specific side effects were observed, except for light pain and discomfort at the site 
study, patients must have abstained from alcohol for at least 6 months. After G-CSF mobilization and leukapheresis, CD $34^{+}$cells were cultured and expanded fivefold in medium supplemented with cytokines (IL-3, G-CSF, $\mathrm{SCF}$, and GM-CSF) for 7 days, when they were harvested and transplanted. Each patient received approximately $2 \times 10^{8}$ cells via hepatic artery. The procedure was well tolerated and the patients had significant decreases in serum bilirubin, seven of them showed an improvement in the Child-Pugh score, while five had an improvement in ascites on imaging (93).

Terai et al. studied nine patients with advanced hepatic cirrhosis. The protocol included aspiration of 400 $\mathrm{ml}$ of bone marrow from the iliac crest region, isolation of mononuclear cells, and infusion via peripheral vein. A significant improvement was observed in the average total protein serum levels, as well as albumin and the Child-Pugh score during the follow-up period of 24 weeks. Five patients showed improvement of ascites. No specific side effects occurred, besides fever on the first day, after the cell infusion, in all the patients (125).

Mohamadnejad et al. evaluated the safety and feasibility of infusing mesenchymal stem cells in four patients with decompensated hepatic cirrhosis. After aspiration from the bone marrow, mesenchymal stem cells were cultivated and reinfused in the peripheral vein. The results demonstrated that no side effects occurred. The MELD score of two patients decreased 3 and 4 points, respectively. The quality of life, evaluated using the SF36 questionnaire, improved in the four patients (19). The same authors reported increased mortality and complications when patients with decompensated cirrhosis were submitted to the transplantation of mesenchymal stem cells using the hepatic artery as administration route and the study was prematurely stopped (80).

Our group carried out a safety and feasibility study, using cell therapy in patients with hepatic cirrhosis (69). Ten patients with advanced chronic liver disease received intrahepatic artery infusions of mononuclear cells collected by bone marrow aspiration. The patients received a 4-month follow-up. The adverse events were minimal, considering that only two patients complained of light pain at the site of the bone marrow tap. No other complication or specific side effects related to the procedure were observed. It was observed a reduction in total bilirubin levels 1 month $(2.19 \pm 0.9 \mathrm{mg} / \mathrm{dl})$ and 4 months $(2.10 \pm 1.0 \mathrm{mg} / \mathrm{dl})$ after the transplant of mononuclear cells, when compared to baseline levels $(2.78 \pm$ $1.2 \mathrm{mg} / \mathrm{dl})$. The serum albumin levels 4 months after the infusion of CMN-MO $(3.73 \pm 0.5 \mathrm{~g} / \mathrm{dl})$ were higher than those at baseline $(3.47 \pm 0.5 \mathrm{~g} / \mathrm{dl})$.

After assessing security and feasibility, our group performed the first controlled, randomized pilot study to evaluate the efficacy of autologous bone marrow cell transplantation in patients with chronic liver disease (68). Thirty patients that were on the liver transplant waiting list joined the study and were randomly selected to receive either cell therapy with bone marrow mononuclear cells (15 patients) or no intervention (15 patients). Autologous mononuclear cells were isolated from bone marrow aspirates and then injected into the hepatic artery. The results showed that the Child-Pugh score improved within 90 days in the cell therapy group, compared to the control group $(p=0.017)$. The MELD figure remained stable in the treated patients, while it increased in the control group during the treatment. The serum albumin levels improved in the treatment group, while remaining stable in the control group in the first 90 days $(p=0.034)$. The serum bilirubin levels increased among the control group patients and decreased in the treatment group during the first 60 days. The effects that were observed did not remain after 90 days. The study conclusions were that transplanting autologous CMN-MO cells via hepatic artery seems to improve liver function in patients with advanced cirrhosis, in the first 90 days (68).

A study performed by am Esch et al. assessed the effects therapy with bone marrow autologous CD133+ cells on hepatic regeneration after selective portal venous embolization in patients with malignant hepatic lesions in preparation for extensive liver ressection. In this unrandomized study, authors compared a group of three patients that were submitted to selective portal venous embolization alone with a group of three patients that received autologous $\mathrm{CD}_{133^{+}}$cells through infusion to nonoccluded hepatic branches after the procedure. The group submitted to the stem cell infusion protocol improved the hepatic regeneration compared to the reference group, as demonstrated by increased daily growth rates and total liver volumes obtained by computed tomography scans (4). This result was also reported in a subsequent work with a larger number of patients and a longer follow up (36).

Summarizing the findings of clinical studies [reviewed in (49)], therapy with bone marrow cells is apparently safe and feasible, and was able to promote increased liver regeneration and improvement in functional liver parameters like serum albumin, bilirubin levels, correlating with improved Child-Pugh and MELD scores. However, most of the available data came from nonrandomized studies with small numbers of patients. Further studies are necessary to define the role of cell therapy in patients with cirrhosis as well as the type of clinical profile of patients that would have the best response to the therapy. Another question that still needs to be resolved is which type of cell possesses the best safety and efficacy to be used in clinical practice. 


\section{FUTURE PERSPECTIVES}

Although the preliminary results of cell therapies in clinical trials of chronic liver diseases are encouraging, we are still a long way to achieve a full reconstitution of the liver damaged by years or decades of chronic pathological processes. It is possible that this kind of therapy is more efficient in initial or intermediate stages of the disease. Because we are still taking the first steps towards the development of a new therapy, many aspects should be addressed in order to improve the effects many issues, including the best cell population to be used, the dose (number of cells), the necessity of repeated doses, and the route of administration, which may very well vary according to the etiology of the liver disease to be approached.

Although embryonic stem cells ate pluripotent and can easily differentiate into specialized cells, their use faces obstacles other than generation of teratocarcinomas due to the lack of histocompatibility with the patient. To overcome the lack of histocompatibility, studies have shown the possibility of reprogramming adult cells, which can be obtained from a biopsy of the patient, through the expression of certain factors by genetic manipulation. These induced pluripotent stem (iPS) cells have properties similar to those embryonic stem cells $(120,121)$ and were generated from mouse and human somatic cells by introduction of four defined transcription factors, Oct 3/4, Sox 2, Klf 4, and c-Myc $(88,121)$. In theory the iPS cells are a therapeutic tool for degenerative diseases. Werning and colleagues showed an amelioration of the symptoms of Parkinson's disease after reprogrammed skin cells in a mouse model (135). Treatment with iPS cells also corrected phenotypically hemophilia A in a murine model (138). The generation of pluripotent stem cells from adult mouse liver cells was obtained though repeated adenoviral infection (118) and genetic lineage tracings show that liver-derived iPS cells are derived from albumin-expressing cells (5). Whether this will represent a practical and safe option for treatment of liver diseases and other pathologies remains to be demonstrated.

The understanding of molecular and cellular mechanisms leading to the repair of the damaged liver may open new avenues for the development of therapeutic strategies more efficient and perhaps less invasive. In this regard, the use of cellular hormones to stimulate the repair the damaged liver by acting in resident cells or by the recruitment of cells from other tissues is an attractive possibility.

ACKNOWLEDGMENTS: This work was supported by grants from FAPESB, RENORBIO, CNPq, FINEP, and by Hospital São Rafael, Bahia-Brazil.

\section{REFERENCES}

1. Abdel Aziz, M. T.; Atta, H. M.; Mahfouz, S.; Fouad, H. H.; Roshdy, N. K.; Ahmed, H. H.; Rashed, L. A.; Sabry, D.; Hassouna, A. A.; Hasan, N. M. Therapeutic potential of bone marrow-derived mesenchymal stem cells on experimental liver fibrosis. Clin. Biochem. 40: 893-899; 2007.

2. Agarwal, S.; Holton, K. L.; Lanza, R. Efficient differentiation of functional hepatocytes from human embryonic stem cells. Stem Cells 26:1117-1127; 2008.

3. Álvarez-Mercado, A. I.; Sáez-Lara, M. J.; Garcia-Mediavilla, M. V.; Sánchez-Campos, S.; Abadía, F.; CabelloDonayre, M.; Gil, A.; González-Gallego, J.; Fontana, L. Xenotransplantation of human umbilical cord blood mononuclear cells to rats with d-galactosamine-induced hepatitis. Cell Transplant. 17(7):845-857; 2008.

4. am Esch, J. S.; Knoefel, W. T.; Klein, M.; Ghodsizad, A.; Fuerst, G.; Poll, L. W.; Piechaczek, C.; Burchardt, E. R.; Feifel, N.; Stoldt, V.; Stockschläder, M.; Stoecklein, N.; Tustas, R. Y.; Eisenberger, C. F.; Peiper, M.; Häussinger, D.; Hosch, S. B. Portal application of autologous CD133+ bone marrow cells to the liver: A novel concept to support hepatic regeneration. Stem Cells 23(4):463470; 2005.

5. Aoi, T.; Yae, K.; Nakagawa, M.; Ichisaka, T.; Okita, K.; Takahashi, K.; Chiba, T.; Yamanaka, S. Generation of pluripotent stem cells from adult mouse liver stomach cells. Science 321:699-702; 2008.

6. Asawa, S.; Saito, T.; Satoh, A.; Ohtake, K.; Tsuchiya, T.; Okada, H.; Neilson, E. G.; Gotoh, M. Participation of bone marrow cells in biliary fibrosis after bile duct ligation. J. Gastroenterol. Hepatol. 22(11):2001-2008; 2007.

7. Baksh, D.; Song, L.; Tuan, R. S. Adult mesenchymal stem cells: characterization, differentiation, and application in cell and gene therapy. J. Cell. Mol. Med. 8(3): 301-316; 2004.

8. Banas, A.; Teratani, T.; Yamamoto, Y.; Tokuhara, M.; Takeshita, F.; Quinn, G.; Okochi, H.; Ochiya, T. Adipose tissue-derived mesenchymal stem cells as a source of human hepatocytes. Hepatology 46(1):219-228; 2007.

9. Belardinelli, M. C.; Pereira, F.; Baldo, G.; Vicente Tavares, A. M.; Kieling, C. O.; da Silveira, T. R.; Meurer, L.; Soares Duarte, M. E.; Giugliani, R.; Matte, U. Adult derived mononuclear bone marrow cells improve survival in a model of acetaminophen-induced acute liver failure in rats. Toxicology 247(1):1-5; 2008.

10. Best, D. H.; Coleman, W. B. Treatment with 2-AAF blocks the small hepatocyte-like progenitor cell response in retrorsine-exposed rats. J. Hepatol. 46:1055-1063; 2007.

11. Bilir, B. M.; Guinette, D.; Karrer, F.; Kumpe, D. A.; Stephens, J.; McGavran, L.; Ostrowska, A.; Durham, J. Hepatocyte transplantation in acute liver failure. Liver Transpl. 6(1):32-40; 2000.

12. Bos, C.; Delmas, Y.; Desmoulière, A.; Solanilla, A.; Hauger, O.; Grosset, C.; Dubus, I.; Ivanovic, Z.; Rosenbaum, J.; Charbord, P.; Combe, C.; Bulte, J. W.; Moonen, C. T.; Ripoche, J.; Grenier, N. In vivo MR imaging of intravascularly injected magnetically labeled mesenchymal stem cells in rat kidney and liver. Radiology 233(3):781-789; 2004.

13. Bruno, S.; Stroffolini, T.; Colombo, M.; Bollani, S.; 
Benvegnù, L.; Mazzella, G.; Ascione, A.; Santantonio, T.; Piccinino, F.; Andreone, P.; Mangia, A.; Gaeta, G. B.; Persico, M.; Fagiuoli, S.; Almasio, P. L.; Italian Association of the Study of the Liver Disease (AISF). Sustained virological response to interferon-alpha is associated with improved outcome in HCV-related cirrhosis: A retrospective study. Hepatology 45(3):579-587; 2007.

14. Camargo, F. D.; Finegold, M.; Goodell, M. A. Hematopoietic myelomonocytic cells are the major source of hepatocyte fusion partners. J. Clin. Invest. 113(9):1266$1270 ; 2004$

15. Cao, B. Q.; Lin, J. Z.; Zhong, Y. S.; Huang, S. B.; Lin, N.; Tang, Z. F.; Chen, R.; Xiang, P.; Xu, R. Y. Contribution of mononuclear bone marrow cells to carbon tetrachloride-induced liver fibrosis in rats. World J. Gastroenterol. 13(12):1851-1854; 2007.

16. Caplan, A. I.; Dennis, J. E. Mesenchymal stem cells as trophic mediators. J. Cell. Biochem. 98(5):1076-1084; 2006

17. Carvalho, A. B.; Quintanilha, L. F.; Dias, J. V.; Paredes, B. D.; Mannheimer, E. G.; Carvalho, F. G.; Asensi, K. D.; Gutfilen, B.; Fonseca, L. M.; Resende, C. M.; Rezende, G. F.; Takiya, C. M.; de Carvalho, A. C.; Goldenberg, R. C. Bone marrow multipotent mesenchymal stromal cells do not reduce fibrosis or improve function in a rat model of severe chronic liver injury. Stem Cells 26(5):1307-1314; 2008

18. Catalina, P.; Cobo, F.; Cortés, J. L.; Nieto, A. I.; Cabrera, C.; Montes, R.; Concha, A.; Menendez, P. Conventional and molecular cytogenetic diagnostic methods in stem cell research: A concise review. Cell Biol. Int. 31(9):861-869; 2007.

19. Corcelle, V.; Stieger, B.; Gjinovci, A.; Wollheim, C. B.; Gauthier, B. R. Characterization of two distinct liver progenitor cell subpopulations of hematopoietic and hepatic origins. Exp. Cell Res. 312(15):2826-2836; 2006.

20. Dahlke, M. H.; Popp, F. C.; Bahlmann, F. H.; Aselmann, H.; Jäger, M. D.; Neipp, M.; Piso, P.; Klempnauer, J.; Schlitt, H. J. Liver regeneration in a retrorsine/ $\mathrm{CCl}_{4}{ }_{-}$ induced acute liver failure model: Do bone marrowderived cells contribute? Hepatology 39(3):365-373; 2003.

21. Dan, Y. Y.; Yeoh, G. C. Liver stem cells: A scientific and clinical perspective. J. Gastroenterol. Hepatol. 23(5): 687-698; 2008

22. Darlington, G. J. Molecular mechanisms of liver development and differentiation. Curr. Opin. Cell Biol. 11(6): 678-682; 1999.

23. Deans, R. J.; Moseley, A. B. Mesenchymal stem cells: Biology and potential clinical uses. Exp. Hematol. 28(8): 875-884; 2000.

24. Deng, X.; Chen, Y. X.; Zhang, X.; Zhang, J. P.; Yin, C.; Yue, H. Y.; Lin, Y.; Han, Z. G.; Xie, W. F. Hepatic stellate cells modulate the differentiation of bone marrow mesenchymal stem cells into hepatocyte-like cells. J. Cell. Physiol. 217(1):138-144; 2008.

25. Dhawan, A.; Mitry, R. R.; Hughes, R. D. Hepatocyte transplantation for liver-based metabolic disorders. J. Inherit. Metab. Dis. 29(2-3):431-435; 2006.

26. Di Campli, C.; Piscaglia, A. C.; Pierelli, L.; Rutella, S.; Bonanno, G.; Alison, M. R.; Mariotti, A.; Vecchio, F. M.; Nestola, M.; Monego, G.; Michetti, F.; Mancuso, S.; Pola, P.; Leone, G.; Gasbarrini, G.; Gasbarrini, A. A human umbilical cord stem cell rescue therapy in a murine model of toxic liver injury. Dig. Liver Dis. 36(9): 603-613; 2004.

27. Duffield, J. S.; Forbes, S. J.; Constandinou, C. M.; Clay, S.; Partolina, M.; Vuthoori, S.; Wu, S.; Lang, R.; Iredale, J. P. Selective depletion of macrophages reveals distinct, opposing roles during liver injury and repair. J. Clin. Invest. 115(1):56-65; 2005.

28. Duncan, S. A. Mechanisms controlling early development of the liver. Mech. Dev. 120(1):19-33; 2003.

29. Duncan, S. A.; Navas, M. A.; Dufort, D.; Rossant, J. Stoffel, M. Regulation of a transcription factor network required for differentiation and metabolism. Science 281(5377):692-695; 1998.

30. Fallowfield, J. A.; Mizuno, M.; Kendall, T. J.; Constandinou, C. M.; Benyon, R. C.; Duffield, J. S.; Iredale, J. P. Scar-associated macrophages are a major source of hepatic matrix metalloproteinase-13 and facilitate the resolution of murine hepatic fibrosis. J. Immunol. 178(8): 5288-5295; 2007

31. Fang, B.; Shi, M.; Liao, L.; Yang, S.; Liu, Y.; Zhao, R. C. Systemic infusion of FLK1(+) mesenchymal stem cells ameliorate carbon tetrachloride-induced liver fibrosis in mice. Transplantation 78(1):83-88; 2004.

32. Fausto, N.; Campbell, J. S.; Riehle, K. J. Liver regeneration. Hepatology 43(S1):S45-S53; 2006.

33. Fischer, U. M.; Harting, M. T.; Jimenez, F.; MonzonPosadas, W. O.; Xue, H.; Savitz, S. I.; Laine, G. A.; Cox, C. S. Pulmonary passage is a major obstacle for intravenous stem cell delivery: The pulmonary first pass effect. Stem Cells Dev. 18(5):683-692; 2009.

34. Fox, I. J.; Chowdhury, J. R. Hepatocyte transplantation. J. Hepatol. 40(6):878-886; 2004.

35. Fox, I. J.; Chowdhury, J. R.; Kaufman, S. S.; Goertzen, T. C.; Chowdhury, N. R.; Warkentin, P. I.; Dorko, K.; Sauter, B. V.; Strom, S. C. Treatment of the CriglerNajjar syndrome type I with hepatocyte transplantation. N. Engl. J. Med. 338(20):1422-1426; 1998.

36. Fürst, G.; Schulte am Esch, J.; Poll, L. W.; Hosch, S. B.; Fritz, L. B.; Klein, M.; Godehardt, E.; Krieg, A.; Wecker, B.; Stoldt, V.; Stockschläder, M.; Eisenberger, C. F.; Mödder, U.; Knoefel, W. T. Portal vein embolisation and autologous CD133+ bone marrow stem cells for liver regeneration: Initial experience. Radiology 243(1): 171-179; 2007.

37. Gaia, S.; Smedile, A.; Omedè, P.; Olivero, A.; Sanavio, F.; Balzola, F.; Ottobrelli, A.; Abate, M. L.; Marzano, A.; Rizzetto, M.; Tarella, C. Feasibility and safety of GCSF administration to induce bone marrow-derived cells mobilization in patients with end stage liver disease. J. Hepatol. 45(1):13-19; 2006.

38. Gewartowska, M.; Olszewski, W. L. Hepatocyte transplantation-biology and application. Ann. Transplant. 12(1):27-36; 2007.

39. Gordon, G. J.; Butz, G. M.; Grisham, J. W.; Coleman, W. B. Isolation, short-term culture, and transplantation of small hepatocyte-like progenitor cells from retrorsineexposed rats. Transplantation 73(8):1236-1243; 2002.

40. Gordon, G. J.; Coleman, W. B.; Grisham, J. W. Temporal analysis of hepatocyte differentiation by small hepatocyte-like progenitor cells during liver regeneration in retrorsine-exposed rats. Am. J. Pathol. 157(3):771-786; 2000 .

41. Gordon, M. Y.; Levicar, N.; Pai, M.; Bachellier, P.; 
Dimarakis, I.; Al-Allaf, F.; M'Hamdi, H.; Thalji, T.; Welsh, J. P.; Marley, S. B.; Davies, J.; Dazzi, F.; Marelli-Berg, F.; Tait, P.; Playford, R.; Jiao, L.; Jensen, S.; Nicholls, J. P.; Ayav, A.; Nohandani, M.; Farzaneh, F.; Gaken, J.; Dodge, R.; Alison, M.; Apperley, J. F.; Lechler, R.; Habib, N. A. Characterization and clinical application of human $\mathrm{CD}^{2} 4^{+}$stem/progenitor cell populations mobilized into the blood by granulocyte colonystimulating factor. Stem Cells 24(7):1822-1830; 2006.

42. Gronthos, S.; Brahim, J.; Li, W.; Fisher, L. W.; Cherman, N.; Boyde, A.; DenBesten, P.; Robey, P. G.; Shi, S. Stem cell properties of human dental pulp stem cells. J. Dent. Res. 81(8):531-535; 2002.

43. Groth, C. G.; Arborgh, B.; Björkén, C.; Sundberg, B.; Lundgren, G. Correction of hyperbilirubinemia in the glucuronyltransferase-deficient rat by intraportal hepatocyte transplantation. Transplant. Proc. 9(1):313-316; 1977.

44. Habibullah, C. M.; Syed, I. H.; Qamar, A. Human fetal hepatocyte transplantation in patients with fulminant hepatic failure. Transplantation 58(8):951-952; 1994.

45. Hewitt, N. J.; Lechón, M. J.; Houston, J. B.; Hallifax, D.; Brown, H. S.; Maurel, P.; Kenna, J. G.; Gustavsson, L.; Lohmann, C.; Skonberg, C.; Guillouzo, A.; Tuschl, G.; Li, A. P.; LeCluyse, E.; Groothuis, G. M.; Hengstler, J. G. Primary hepatocytes: Current understanding of the regulation of metabolic enzymes and transporter proteins, and pharmaceutical practice for the use of hepatocytes in metabolism, enzyme induction, transporter, clearance, and hepatotoxicity studies. Drug. Metab. Rev. 39(1):159-234; 2007.

46. Higashiyama, R.; Inagaki, Y.; Hong, Y. Y.; Kushida, M.; Nakao, S.; Niioka, M.; Watanabe, T.; Okano, H.; Matsuzaki, Y.; Shiota, G.; Okazaki, I. Bone marrow-derived cells express matrix metalloproteinases and contribute to regression of liver fibrosis in mice. Hepatology 45(1): 213-222; 2007.

47. Hong, S. H.; Gang, E. J.; Jeong, J. A.; Ahn, C.; Hwang, S. H.; Yang, I. H.; Park, H. K.; Han, H.; Kim, H. In vitro differentiation of human umbilical cord blood-derived mesenchymal stem cells into hepatocyte-like cells. Biochem. Biophys. Res. Commun. 330(4):1153-1161; 2005.

48. Horslen, S. P.; McCowan, T. C.; Goertzen, T. C.; Warkentin, P. I.; Cai, H. B.; Strom, S. C.; Fox, I. J. Isolated hepatocyte transplantation in an infant with a severe urea cycle disorder. Pediatrics 111:1262-1267; 2003.

49. Houlihan, D. D.; Newsome, P. N. Critical review of clinical trials of bone marrow stem cells in liver disease. Gastroenterology 135:438-450; 2008.

50. Ishikawa, F.; Drake, C. J.; Yang, S.; Fleming, P.; Minamiguchi, H.; Visconti, R. P.; Crosby, C. V.; Argraves, W. S.; Harada, M.; Key, Jr., L. L.; Livingston, A. G.; Wingard, J. R.; Ogawa, M. Transplanted human cord blood cells give rise to hepatocytes in engrafted mice. Ann. NY Acad. Sci. 996:174-185; 2003.

51. Jang, Y. Y.; Collector, M. I.; Baylin, S. B.; Diehl, A. M.; Sharkis, S. J. Hematopoietic stem cells convert into liver cells within days without fusion. Nat. Cell Biol. 6(6): 532-539; 2004.

52. Jung, J.; Zheng, M.; Goldfarb, M.; Zaret, K. S. Initiation of mammalian liver development from endoderm by fibroblast growth factors. Science 284(5422):1998-2003; 1999.

53. Kakinuma, S.; Tanaka, Y.; Chinzei, R.; Watanabe, M.; Shimizu-Saito, K.; Hara, Y.; Teramoto, K.; Arii, S.; Sato,
C.; Takase, K.; Yasumizu, T.; Teraoka, H. Human umbilical cord blood as a source of transplantable hepatic progenitor cells. Stem Cells 21(2):217-227; 2003.

54. Kang, X. Q.; Zang, W. J.; Bao, L. J.; Li, D. L.; Song, T. S.; Xu, X. L.; Yu, X. J. Fibroblast growth factor-4 and hepatocyte growth factor induce differentiation of human umbilical cord blood-derived mesenchymal stem cells into hepatocytes. World J. Gastroenterol. 11(47):7461$7465 ; 2005$

55. Kang, X. Q.; Zang, W. J.; Song, T. S.; Xu, X. L.; Yu, X. J.; Li, D. L.; Meng, K. W.; Wu, S. L.; Zhao, Z. Y. Rat bone marrow mesenchymal stem cells differentiate into hepatocytes in vitro. World J. Gastroenterol. 11(22): 3479-3484; 2005.

56. Khan, A. A.; Habeeb, A.; Parveen, N.; Naseem, B.; Babu, R. P.; Capoor, A. K.; Habibullah, C. M. Peritoneal transplantation of human fetal hepatocytes for the treatment of acute fatty liver of pregnancy: A case report. Trop. Gastroenterol. 25(3):141-143; 2004.

57. Kisseleva, T.; Uchinami, H.; Feirt, N. Bone marrowderived fibrocytes participate in pathogenesis of liver fibrosis. J. Hepatol. 45(3):429-438; 2006.

58. Kobayashi, N.; Ito, M.; Nakamura, J.; Cai, J.; Gao, C.; Hammel, J. M.; Fox, I. J. Hepatocyte transplantation in rats with decompensated cirrhosis. Hepatology 31(4): 851-857; 2000.

59. Kubota, K.; Soeda, J.; Misawa, R.; Mihara, M.; Miwa, S.; Ise, H.; Takahashi, M.; Miyagawa, S. Bone marrowderived cells fuse with hepatic oval cells but are not involved in hepatic tumorigenesis in the choline-deficient ethionide-supplemented diet rat model. Carcinogenesis 29(2):448-454; 2008.

60. Kuo, T. K.; Hung, S. P.; Chuang, C. H.; Chen, C. T.; Shih, Y.; Fang, S. C.; Yang, V. W.; Lee, O. K. Stem cell therapy for liver disease: Parameters governing the success of using bone marrow mesenchymal stem cells. Gastroenterology 134(7):2111-2121; 2008.

61. Kurdistani, S. K.; Grunstein, M. Histone acetylation and deacetylation in yeast. Nat. Rev. Mol. Cell Biol. 4(4): 276-284; 2003.

62. LaBrecque, D. Liver regeneration: A picture emerges from the puzzle. J. Gastroenterol. 89(8):586-596; 1994.

63. Lagasse, E.; Connors, H.; Al-Dhalimy, M.; Reitsma, M.; Dohse, M.; Osborne, L.; Wang, X.; Finegold, M.; Weissman, I. L.; Grompe, M. Purified hematopoietic stem cells can differentiate into hepatocytes in vivo. Nat. Med. 6(11):1229-1234; 2000.

64. Levicar, N.; Pai, M.; Habib, N. A.; Tait, P.; Jiao, L. R.; Marley, S. B.; Davis, J.; Dazzi, F.; Smadja, C.; Jensen, S. L.; Nicholls, J. P.; Apperley, J. F.; Gordon, M. Y. Long-term clinical results of autologous infusion of mobilized adult bone marrow derived $\mathrm{CD}^{+} 4^{+}$cells in patients with chronic liver disease. Cell Prolif. 41(S1):115$125 ; 2008$.

65. Li, W. L.; Su, J.; Yao, Y. C.; Tao, X. R.; Yan, Y. B.; Yu, H. Y.; Wang, X. M.; Li, J. X.; Yang, Y. J.; Lau, J. T.; Hu, Y. P. Isolation and characterization of bipotent liver progenitor cells from adult mouse. Stem Cells 24(2):322-332; 2006.

66. Lin, N.; Tang, Z.; Deng, M.; Zhong, Y.; Lin, J.; Yang, $\mathrm{X}$; Xiang, P.; Xu, R. Hedgehog-mediated paracrine interaction between hepatic stellate cells and marrowderived mesenchymal stem cells. Biochem. Biophys. Res. Commun. 372(1):260-265; 2008. 
67. Lorenzo-Zúñiga, V.; Rodríguez-Ortigosa, C. M.; Bartolí, R.; Martínez-Chantar, M. L.; Martínez-Peralta, L.; Pardo, A.; Ojanguren, I.; Quiroga, J.; Planas, R.; Prieto, J. Insulin-like growth factor-I improves intestinal barrier function in cirrhotic rats. Gut 55(9):1306-1312; 2006.

68. Lyra, A. C.; Soares, M. B. P.; da Silva, L. F. M.; Braga, E. L.; Oliveira, S. A.; Fortes, M.; Goyanna, A.; Brustolim, D.; Genser, B.; Santos, R. R.; Lyra, L. G. C. Infusion of autologous bone marrow mononuclear cells through hepatic artery results in a short-term improvement of liver function in patients with chronic liver disease: A pilot randomized controlled study. Eur. J. Gastroenterol. Hepatol. (in press).

69. Lyra, A. C.; Soares, M. B. P.; da Silva, L. F. M.; Fortes, M. F.; Silva, A. G.; Mota, A. C.; Oliveira, S. A.; Braga, E. L.; de Carvalho, W. A.; Genser, B.; dos Santos, R. R.; Lyra, L. G. Feasibility and safety of autologous bone marrow mononuclear cell transplantation in patients with advanced chronic liver disease. World J. Gastroenterol. 13(7):1067-1073; 2007.

70. Martin, G. R. Isolation of a pluripotent cell line from early mouse embryos cultured in medium conditioned by teratocarcinoma stem cells. Proc. Natl. Acad. Sci. USA 78(12):7634-7638; 1981.

71. Masson, S.; Harrison, D. J.; Plevris, J. N.; Newsome, P. N. Potential of hematopoietic stem cell therapy in hepatology: A critical review. Stem Cells 22(6):897-907; 2004.

72. Matas, A. J.; Sutherland, D. E.; Steffes, M. W.; Mauer, S. M.; Sowe, A.; Simmons, R. L.; Najarian, J. S. Hepatocellular transplantation for metabolic deficiencies: Decrease of plasms bilirubin in Gunn rats. Science 192(4242):892-894; 1976.

73. McLin, V. A.; Zorn, A. M. Molecular control of liver development. Clin. Liver Dis. 10(1):1-25; 2006.

74. Minato, M.; Houssin, D.; Demma, I.; Morin, J.; Gigou, M.; Szekely, A. M.; Bismuth, H. Transplantation of hepatocytes for treatment of surgically induced acute hepatic failure in the rat. Eur. Surg. Res. 16(3):162-169; 1984.

75. Mitalipova, M. M.; Rao, R. R.; Hoyer, D. M.; Johnson, J. A.; Meisner, L. F.; Jones, K. L.; Dalton, S.; Stice, S. L. Preserving the genetic integrity of human embryonic stem cells. Nat. Biotechnol. 23(1):19-20; 2005.

76. Mito, M.; Kusano, M.; Kawaura, Y. Hepatocyte transplantation in man. Transplant. Proc. 24(6):3052-3053; 1992.

77. Miyajima, A.; Kinoshita, T.; Tanaka, M.; Kamiya, A.; Mukouyama, Y.; Hara, T. Role of Oncostatin M in hematopoiesis and liver development. Cytokine Growth Factor Rev. 11(3):177-183; 2000.

78. Miyata, E.; Masuya, M.; Yoshida, S.; Nakamura, S.; Kato, K.; Sugimoto, Y.; Shibasaki, T.; Yamamura, K.; Ohishi, K.; Nishii, K.; Ishikawa, F.; Shiku, H.; Katayama, N. Hematopoietic origin of hepatic stellate cells in the adult liver. Blood 111(4):2427-2435; 2008.

79. Mohamadnejad, M.; Alimoghaddam, K.; MohyeddinBonab, M.; Bagheri, M.; Bashtar, M.; Ghanaati, H.; Baharvand, H.; Ghavamzadeh, A.; Malekzadeh, R. Phase 1 trial of autologous bone marrow mesenchymal stem cell transplantation in patients with decompensated liver cirrhosis. Arch. Iran. Med. 10(4):459-466; 2007.

80. Mohamadnejad, M.; Namiri, M.; Bagheri, M.; Hashemi, S. M.; Ghanaati, H.; Zare Mehrjardi, N.; Kazemi Ashti- ani, S.; Malekzadeh, R.; Baharvand, H. Phase 1 human trial of autologous bone marrow-hematopoietic stem cell transplantation in patients with decompensated cirrhosis. World J. Gastroenterol. 13(24):3359-3363; 2007.

81. Muraca, M.; Gerunda, G.; Néri, D.; Vilei, M. T.; Granato, A.; Feltracco, P.; Meroni, M.; Giron, G.; Burlina, A. B. Hepatocyte transplantation as a treatment for glycogen storage disease type 1a. Lancet 359(9303): 317-318; 2002.

82. Nagy, A.; Gocza, E.; Diaz, E. M. Embryonic stem cells alone are able to support fetal development in the mouse. Development 110(3):815-821; 1990.

83. Nagy, A.; Rossant, J.; Nagy, R.; Abramow-Newerly, W.; Roder, J. C. Derivation of completely cell culturederived mice from early-passage embryonic stem cells. Proc. Natl. Acad. Sci. USA 90(18):8424-8428; 1993.

84. Najimi, M.; Khuu, D. N.; Lysy, P. A.; Jazouli, N.; Abarca, J.; Sempoux, C.; Sokal, E. M. Adult-derived human liver mesenchymal-like cells as a potential progenitor reservoir of hepatocytes? Cell Transplant. 16(7):717$728 ; 2007$.

85. Newsome, P. N.; Johannessen, I.; Boyle, S.; Dalakas, E.; McAulay, K. A.; Samuel, K.; Rae, F.; Forrester, L.; Turner, M. L.; Hayes, P. C.; Harrison, D. J.; Bickmore, W. A.; Plevris, J. N. Human cord blood-derived cells can differentiate into hepatocytes in the mouse liver with no evidence of cellular fusion. Gastroenterology 124(7): 1891-1900;

86. Oh, S. H.; Hatch, H. M.; Petersen, B. E. Hepatic oval 'stem' cell in liver regeneration. Semin. Cell. Dev. Biol. 13(6):405-409; 2002.

87. Okano, K.; Tsubouchi, T.; Yamashita, Y.; Wakabayashi, H.; Maeba, T.; Maeta, H.; Tanaka, S. Hepatic protein synthesis in the regenerating rat liver after hepatopancreatectomy. Surg. Today 27(6):511-517; 1997.

88. Okita, K.; Ichisaka, T.; Yamanaka, S. Generation of germline-competent induced pluripotent stem cells. Nature 448(7151):313-317; 2007.

89. Oliveira, S. A.; Souza, B. S.; Guimarães-Ferreira, C. A.; Barreto, E. S.; Souza, S. C.; Freitas, L. A.; Ribeiro-DosSantos, R.; Soares, M. B. Therapy with bone marrow cells reduces liver alterations in mice chronically infected by Schistosoma mansoni. World J. Gastroenterol. 14(38):5842-5850; 2008.

90. Ong, S. Y.; Dai, H.; Leong, K. W. Inducing hepatic differentiation of human mesenchymal stem cells in pellet culture. Biomaterials 27(22):4087-4097; 2006.

91. Oyagi, S.; Hirose, M.; Kojima, M.; Okuyama, M.; Kawase, M.; Nakamura, T.; Ohgushi, H.; Yagi, K. Therapeutic effect of transplanting HGF-treated bone marrow mesenchymal cells into $\mathrm{CCl}_{4}$-injured rats. J. Hepatol. 44(4):742-748; 2006.

92. Pahal, G. S.; Jauniaux, E.; Kinnon, C.; Thrasher, A. J.; Rodeck, C. H. Normal development of human fetal hematopoiesis between eight and seventeen weeks? gestation. Am. J. Obstet. Gynecol. 183(4):1029-1034; 2000 .

93. Pai, M.; Zacharoulis, D.; Milicevic, M. N.; Helmy, S.; Jiao, L. R.; Levicar, N.; Tait, P.; Scott, M.; Marley, S. B.; Jestice, K.; Glibetic, M.; Bansi, D.; Khan, S. A.; Kyriakou, D.; Rountas, C.; Thillainayagam, A.; Nicholls, J. P.; Jensen, S.; Apperley, J. F.; Gordon, M. Y.; Habib, N. A. Autologous infusion of expanded mobilized adult bone marrow-derived $\mathrm{CD} 34^{+}$cells into patients with al- 
coholic liver cirrhosis. Am. J. Gastroenterol. 103(8): 1952-1958; 2008.

94. Parviz, F.; Matullo, C.; Garrison, W. D.; Savatski, L.; Adamson, J. W.; Ning, G.; Kaestner, K. H.; Rossi, J. M.; Zaret, K. S.; Duncan, S. A. Hepatocyte nuclear factor 4alpha controls the development of a hepatic epithelium and liver morphogenesis. Nat. Genet. 34(3):292-296; 2003.

95. Petersen, B. E.; Bowen, W. C.; Patrene, K. D.; Mars, W. M.; Sullivan, A. K.; Murase, N.; Boggs, S. S.; Greenberger, J. S.; Goff, J. P. Bone marrow as a potential source of hepatic oval cells. Science 284(5417):1168$1170 ; 1999$.

96. Petersen, B. E.; Goff, J. P.; Greenberger, J. S.; Michalopoulos, G. K. Hepatic oval cells express the hematopoietic stem cell marker Thy-1 in the rat. Hepatology 27(2): 433-445; 1998.

97. Piscaglia, A. C.; Shupe, T. D.; Oh, S. H.; Gasbarrini, A.; Petersen, B. E. Granulocyte-colony stimulating factor promotes liver repair and induces oval cell migration and proliferation in rats. Gastroenterology 133(2):619-631; 2007.

98. Piscaglia, A. C.; Zocco, M. A.; Di Campli, C.; Sparano, L.; Rutella, S.; Monego, G.; Bonanno, G.; Michetti, F.; Mancuso, S.; Pola, P.; Leone, G.; Gasbarrini, G.; Gasbarrini, A. How does human stem cell therapy influence gene expression after liver injury? Microarray evaluation on a rat model. Dig. Liver Dis. 37(12):952-963; 2005.

99. Quaglia, A.; Lehec, S. C.; Hughes, R. D.; Mitry, R. R.; Knisely, A. S.; Devereaux, S.; Richards, J.; Rela, M.; Heaton, N. D.; Portmann, B. C.; Dhawan, A. Liver after hepatocyte transplantation for liver-based metabolic disorders in children. Cell Transplant. 17(12):1403-1414; 2008.

100. Quintana-Bustamante, O.; Alvarez-Barrientos, A.; Kofman, A. V.; Fabregat, I.; Bueren, J. A.; Theise, N. D.; Segovia, J. C. Hematopoietic mobilization in mice increases the presence of bone marrow-derived hepatocytes via in vivo cell fusion. Hepatology 43(1):108-116; 2006.

101. Rasmusson, I. Immune modulation by mesenchymal stem cells. Exp. Cell. Res. 312(12):2169-2179; 2006.

102. Rubio, D.; Garcia-Castro, J.; Martín, M. C.; de la Fuente, R.; Cigudosa, J. C.; Lloyd, A. C.; Bernad, A. Spontaneous human adult stem cell transformation. Cancer Res. 65(8):3035-3039; 2005.

103. Ruhnke, M.; Nussler, A. K.; Ungefroren, H.; Hengstler, J. G.; Kremer, B.; Hoeckh, W.; Gottwald, T.; Heeckt, P.; Fandrich, F. Human monocyte-derived neohepatocytes: A promising alternative to primary human hepatocytes for autologous cell therapy. Transplantation 79(9):1097$1103 ; 2005$.

104. Russo, F. P.; Alison, M. R.; Bigger, B. W.; Amofah, E.; Florou, A.; Amin, F.; Bou-Gharios, G.; Jeffery, R.; Iredale, J. P.; Forbes, S. J. The bone marrow functionally contributes to liver fibrosis. Gastroenterology 130(6): 1807-1821; 2006.

105. Sakai, Y.; Jiang, J.; Kojima, N.; Kinoshita, T.; Miyajima, A. Enhanced in vitro maturation of fetal mouse liver cells with oncostatin $\mathrm{M}$, nicotinamide, and dimethyl sulfoxide. Cell Transplant. 11(5):435-441; 2002.

106. Sakaida, I.; Terai, S.; Nishina, H.; Okita, K. Development of cell therapy using autologous bone marrow cells for liver cirrhosis. Med. Mol. Morphol. 38(4):197-202; 2005 .
107. Sakaida, I.; Terai, S.; Yamamoto, N.; Aoyama, K.; Ishikawa, T.; Nishina, H.; Okita, K. Transplantation of bone marrow cells reduces $\mathrm{CCl}_{4}$-induced liver fibrosis in mice. Hepatology 40(6):1304-1311; 2004.

108. Sanz, S.; Pucilowska, J. B.; Liu, S.; Rodríguez-Ortigosa, C. M.; Lund, P. K.; Brenner, D. A.; Fuller, C. R.; Simmons, J. G.; Pardo, A.; Martínez-Chantar, M. L.; Fagin, J. A.; Prieto, J. Expression of insulin-like growth factor I by activated hepatic stellate cells reduces fibrogenesis and enhances regeneration after liver injury. Gut 54(1):134-141; 2005.

109. Sasaki, K.; Kon, J.; Mizuguchi, T.; Chen, Q.; Ooe, H.; Oshima, H.; Hirata, K.; Mitaka, T. Proliferation of hepatocyte progenitor cells isolated from adult human livers in serum-free medium. Cell Transplant. 17(10-11): 1221-1230; 2008.

110. Sell, S. Heterogeneity and plasticity of hepatocyte lineage cells. Hepatology 33(3):738-750; 2001.

111. Sgroi, A.; Serre-Beinier, V.; Morel, P.; Bühler, L. What clinical alternatives to whole liver transplantation? Current status of artificial devices and hepatocyte transplantation. Transplantation 87(4):457-466; 2009.

112. Snykers, S.; Vanhaecke, T.; De Becker, A.; Papeleu, P.; Vinken, M.; Van Riet, I.; Rogiers, V. Chromatin remodeling agent trichostatin A: A key-factor in the hepatic differentiation of human mesenchymal stem cells derived of adult bone marrow. BMC Dev. Biol. 7:24; 2007.

113. Snykers, S.; Vanhaecke, T.; Papeleu, P.; Luttun, A.; Jiang, Y.; Vander Heyden, Y.; Verfaillie, C.; Rogiers, V. Sequential exposure to cytokines reflecting embryogenesis: The key for in vitro differentiation of adult bone marrow stem cells into functional hepatocyte-like cells. Toxicol. Sci. 94(2):330-341; 2006.

114. Solter, D. From teratocarcinomas to embryonic stem cells and beyond: A history of embryonic stem cell research. Nat. Rev. Genet. 7(4):319-327; 2006.

115. Song, S.; Witek, R. P.; Lu, Y.; Choi, Y. K.; Zheng, D.; Jorgensen, M.; Li, C.; Flotte, T. R.; Petersen, B. E. Ex vivo transduced liver progenitor cells as a platform for gene therapy in mice. Hepatology 40(4):918-924; 2004.

116. Soto-Gutierrez, A.; Navarro-Alvarez, N.; CaballeroCorbalan, J.; Tanaka, N.; Kobayashi, N. Endoderm induction for hepatic and pancreatic differentiation of ES cells. Acta Med. Okayama 62(2):63-68; 2008.

117. Spahr, L.; Lambert, J. F.; Rubbia-Brandt, L.; Chalandon, Y.; Frossard, J. L.; Giostra, E.; Hadengue, A. Granulocyte-colony stimulating factor induces proliferation of hepatic progenitors in alcoholic steatohepatitis: A randomized trial. Hepatology 48(1):221-229; 2008.

118. Stadtfeld, M.; Nagaya, M.; Utikal, J.; Weir, G.; Hochedlinger, K. Induced pluripotent stem cells generated without viral integration. Science 322:945-949; 2008.

119. Sung, J. H.; Yang, H. M.; Park, J. B.; Choi, G. S.; Joh, J. W.; Kwon, C. H.; Chun, J. M.; Lee, S. K.; Kim, S. J. Isolation and characterization of mouse mesenchymal stem cells. Transplant. Proc. 40(8):2649-2654; 2008.

120. Takahashi, K.; Okita, K.; Nakagawa, M.; Yamanaka, S. Induction of pluripotent stem cells from adult human fibroblasts by defined factors. Cell 131(5):861-872; 2007.

121. Takahashi, K.; Yamanaka, S. Induction of pluripotent stem cels from mouse embryonic and adult fibroblast cultures by defined factors. Cell 126(4):663-676; 2006.

122. Taléns-Visconti, R.; Bonora, A.; Jover, R.; Mirabet, V.; Carbonell, F.; Castell, J. V.; Gómez-Lechón, M. J. Hepa- 
togenic differentiation of human mesenchymal stem cells from adipose tissue in comparison with bone marrow mesenchymal stem cells. World J. Gastroenterol. 12(36): 5834-5845; 2006.

123. Tamayo, R. P. Is cirrhosis of the liver experimentally produced by $\mathrm{CCL}_{4}$ an adequate model of human cirrhosis? Hepatology 3(1):112-120; 1983.

124. Tang, X. P.; Yang, X.; Tan, H.; Ding, Y. L.; Zhang, M.; Wang, W. L. Clinical and experimental study on therapeutic effect of umbilical cord blood transplantation on severe viral hepatitis. World J. Gastroenterol. 9(9):1999_ 2003; 2003.

125. Terai, S.; Ishikawa, T.; Omori, K.; Aoyama, K.; Marumoto, Y.; Urata, Y.; Yokoyama, Y.; Uchida, K.; Yamasaki, T.; Fujii, Y.; Okita, K.; Sakaida, I. Improved liver function in patients with liver cirrhosis after autologous bone marrow cell infusion therapy. Stem Cells 24(10): 2292-2298; 2006.

126. Theise, N. D.; Krause, D. S. Toward a new paradigm of cell plasticity. Leukemia 16(4):542-548; 2002.

127. Theise, N. D.; Nimmakayalu, M.; Gardner, R.; Illei, P. B.; Morgan, G.; Teperman, L.; Henegariu, O.; Krause, D. S. Liver from bone marrow in humans. Hepatology 32(1): 11-16; 2000.

128. Theise, N. D.; Saxena, R.; Portmann, B. C.; Thung, S. N.; Yee, H.; Chiriboga, L.; Kumar, A.; Crawford, J. M. The canals of Herring and hepatic stem cells in humans. Hepatology 30(6):1425-1433; 1999.

129. van Poll, D.; Parekkadan, B.; Cho, C. H.; Berthiaume, F.; Nahmias, Y.; Tilles, A. W.; Yarmush, M. L. Mesenchymal stem cell-derived molecules directly modulate hepatocellular death and regeneration in vitro and in vivo. Hepatology 47(5):1634-1643; 2008.

130. Vassilopoulos, G.; Wang, P. R.; Russell, D. W. Transplanted bone marrow regenerates liver by cell fusion. Nature 422(6934):901-904; 2003.

131. Vig, P.; Russo, F. P.; Edwards, R. J.; Tadrous, P. J.; Wright, N. A.; Thomas, H. C.; Alison, M. R.; Forbes, S. J. The sources of parenchymal regeneration after chronic hepatocellular liver injury in mice. Hepatology 43(2):316-324; 2006.

132. Wang, X.; Foster, M.; Al-Dhalimy, M.; Lagasse, E.; Finegold, M.; Grompe, M. The origin and liver repopulating capacity of murine oval cells. Proc. Natl. Acad. Sci. USA 100(1):11881-11888; 2003.

133. Wang, X.; Willenbring, H.; Akkari, Y.; Torimaru, Y.; Foster, M.; Al-Dhalimy, M.; Lagasse, E.; Finegold, M.; Olson, S.; Grompe, M. Cell fusion is the principal source of bone-marrow-derived hepatocytes. Nature 422(6934): 897-901; 2003.

134. Weber, A.; Groyer-Picard, M. T.; Franco, D.; Dagher, I. Hepatocyte transplantation in animal models. Liver Transpl. 15(1):7-14; 2009.

135. Wernig, M.; Zhao, J. P.; Pruszak, J.; Hedlund, E.; Fu, D.; Soldner, F.; Broccoli, V.; Constantine-Paton, M.; Isacson, O.; Jaenisch, R. Neurons derived from repro- grammed fibroblasts functionally integrate into the fetal brain and improve symptoms of rats with Parkinson's disease. Proc. Natl. Acad. Sci. USA 105:5856-5861; 2008.

136. Willenbring, H.; Bailey, A. S.; Foster, M.; Akkari, Y.; Dorrell, C.; Olson, S.; Finegold, M.; Fleming, W. H.; Grompe, M. Myelomonocytic cells are sufficient for therapeutic cell fusion in liver. Nat. Med. 10(7):744$748 ; 2004$.

137. Xia, J. L.; Dai, C.; Michalopoulos, G. K.; Liu, Y. Hepatocyte growth factor attenuates liver fibrosis induced by bile duct ligation. Am. J. Pathol. 168(5):1500-1512; 2006.

138. Xu, D.; Alipio, Z.; Fink, L. M.; Adcock, D. M.; Yang, J.; Ward, D. C.; Ma, Y. Phenotypic correction of murine hemophilia A using an iPS cell-based therapy. Proc. Natl. Acad. Sci. USA 106(3):808-813; 2009.

139. Yannaki, E.; Anagnostopoulos, A.; Kapetanos, D. Xagorari, A.; Iordanidis, F.; Batsis, I.; Kaloyannidis, P.; Athanasiou, E.; Dourvas, G.; Kitis, G.; Fassas, A. Lasting amelioration in the clinical course of decompensated alcoholic cirrhosis with boost infusions of mobilized peripheral blood stem cells. Exp. Hematol. 34(11):15831587; 2006.

140. Yannaki, E.; Athanasiou, E.; Xagorari, A.; Constantinou, V.; Batsis, I.; Kaloyannidis, P.; Proya, E.; Anagnostopoulos, A.; Fassas, A. G-CSF-primed hematopoietic stem cells or G-CSF per se accelerate recovery and improve survival after liver injury, predominantly by promoting endogenous repair programs. Exp. Hematol. 33(1):108$119 ; 2005$.

141. Yin, L.; Lynch, D.; Ilic, Z.; Sell, S. Proliferation and differentiation of ductular progenitor cells and littoral cells during the regeneration of the rat liver to $\mathrm{CCl}_{4} / 2-\mathrm{AAF}$ injury. Histol. Histopathol. 17(1):65-81; 2002.

142. Yoshida, M.; Kijima, M.; Akita, M.; Beppu, T. Potent and specific inhibition of mammalian histone deacetylase both in vivo and in vitro by trichostatin A. J. Biol. Chem. 265(28):17174-17179; 1990.

143. Zaret, K. S. Hepatocyte differentiation: From the endoderm and beyond. Curr. Opin. Genet. Dev. 11(5):568574; 2001.

144. Zaret, K. S. Liver specification and early morphogenesis. Mech. Dev. 92(1):83-88; 2000.

145. Zhao, D. C.; Lei, J. X.; Chen, R.; Yu, W. H.; Zhang, X. M.; Li, S. N.; Xiang, P. Bone marrow-derived mesenchymal stem cells protect against experimental liver fibrosis in rats. World J. Gastroenterol. 11(22):34313440; 2005 .

146. Zhao, Y.; Glesne, D.; Huberman, E. A human peripheral blood monocyte-derived subset acts as pluripotent stem cells. Proc. Natl. Acad. Sci. USA 100(5):2426-2431; 2003.

147. Zheng, J. F.; Liang, L. J. Intra-portal transplantation of bone marrow stromal cells ameliorates liver fibrosis in mice. Hepatobiliary Pancreat. Dis. Int. 7(3):264-270; 2008. 
